NBER WORKING PAPER SERIES

HEALTH AND MENTAL HEALTH EFFECTS OF LOCAL IMMIGRATION ENFORCEMENT

\author{
Julia Shu-Huah Wang \\ Neeraj Kaushal \\ Working Paper 24487 \\ http://www.nber.org/papers/w24487 \\ NATIONAL BUREAU OF ECONOMIC RESEARCH \\ 1050 Massachusetts Avenue \\ Cambridge, MA 02138 \\ April 2018
}

We thank Julien Teitler, Irwin Garfinkel, Yao Lu, Prakash Gorroochurn and anonymous reviewers for valuable suggestions at various stages of this project. Julia Shu-Huah Wang gratefully acknowledges funding support from the Horowitz Foundation for Social Policy Research and the UC Davis Center for Poverty Research. The views expressed herein are those of the authors and do not necessarily reflect the views of the National Bureau of Economic Research.

NBER working papers are circulated for discussion and comment purposes. They have not been peer-reviewed or been subject to the review by the NBER Board of Directors that accompanies official NBER publications.

(C) 2018 by Julia Shu-Huah Wang and Neeraj Kaushal. All rights reserved. Short sections of text, not to exceed two paragraphs, may be quoted without explicit permission provided that full credit, including $\odot$ notice, is given to the source. 
Health and Mental Health Effects of Local Immigration Enforcement

Julia Shu-Huah Wang and Neeraj Kaushal

NBER Working Paper No. 24487

April 2018

JEL No. I1,I14,I3,J15,J18

\begin{abstract}
$\underline{\text { ABSTRACT }}$
We study the effect of two local immigration enforcement policies - Section 287(g) of the Illegal Immigration Reform and Immigrant Responsibility Act and the Secure Communities Program (SC) - that have escalated fear and risk of deportation among the undocumented on the health and mental health outcomes of Latino immigrants living in the United States. We use the restricted-use National Health Interview Survey for 2000-2012 and adopt a difference-indifference research design. Estimates suggest that SC increased the proportion of Latino immigrants with mental health distress by 2.2 percentage points (14.7 percent); Task Force Enforcement under Section 287(g) worsened their mental health distress scores by 15 percent (0.08 standard deviation); Jail Enforcement under Section 287(g) increased the proportion of Latino immigrants reporting fair or poor health by 1 percentage point (11.1 percent) and lowered the proportion reporting very good or excellent health by 4.8 to 7.0 percentage points (7.8 to 10.9 percent). These findings are robust across various sensitivity checks.
\end{abstract}

Julia Shu-Huah Wang

The University of Hong Kong

Hong Kong

jshwang@hku.hk

Neeraj Kaushal

Columbia University

School of Social Work

1255 Amsterdam Avenue

New York, NY 10027

and NBER

nk464@columbia.edu 


\section{Health and Mental Health Effects of Local Immigration Enforcement}

\section{INTRODUCTION}

Over the past decade, the terrain of immigration enforcement in the United States has expanded from national borders to local and state jurisdictions, resulting in an increasing number of arrests on grounds of immigration status and national origin (Lacayo, 2010). ${ }^{1}$ Involvement of local and state governments in immigration enforcement intensifies fears of deportation and is likely to cause stress and adversely impact the physical and mental health of undocumented immigrants and their family members, many of whom may be U.S. citizens. ${ }^{2}$ Local enforcement is also likely to make undocumented immigrants and their families more vulnerable to workplace exploitation, reduce their social interactions and use of essential public services, and generally increase mistrust towards public institutions, in particular local law enforcement agencies (Gleeson, 2014; Hacker et al., 2011; Hardy et al., 2011; Rhodes et al., 2015).

Previous research documents that local and state government participation in immigration enforcement has affected immigrant settlement patterns, employment, and earnings, and patterns of farm labor use and farm profitability (Pham \& Van, 2010; Capps, Rosenblum, Rodriquez, \& Chishti. 2011; Kostandini, Mykerezi, \& Escalante, 2013; Watson, 2013). Local or state-specific studies using qualitative approaches also suggest that local enforcement increased stress and anxiety among immigrants and deterred them from seeking health services (Rhodes et al., 2015;

\footnotetext{
${ }^{1}$ During 2006-2012, local officials deputized under 287(g) arrested 256,330 undocumented immigrants (ICE FOIA, 2015). In 2008, the number of removals under 287 (g) represented 9.5\% of all ICE immigrant removals, with a noninsignificant number being removed based on minor traffic offenses such as driving without license or driving under the influence (Lacayo, 2010; Vaughan \& Edwards, 2009).

${ }^{2}$ In the 2008 National Survey of Latinos administered by Pew Hispanic Center, nearly 10\% of Hispanic adults (both native-born and immigrants) reported being asked by the police or other authorities about their immigration status in the past year, and 35\% of native-born Hispanic citizens said that they worried "a lot or some" about deportation of relatives, or friends (Lopez \& Minushikin, 2008). Lacayo (2010) cites anecdotal evidence of Latinos being subject to racial profiling and were increasingly pulled over and interrogated for minor offenses as an excuse to check their documentation status.
} 
Hacker et al., 2011). There is, however, little systematic national research on health and mental health effects of local immigration enforcement, resulting in a critical knowledge gap on the full range of impacts of what has become a salient feature of the U.S. government's approach to undocumented immigration and is being vigorously pursued by the Trump administration.

In this paper, we bridge this knowledge gap by investigating the effects of two local enforcement policy initiatives: Section 287(g) of the Illegal Immigration Reform and Immigrant Responsibility Act (IIRIRA) and the Secure Communities program (SC). Section 287(g) gave local jurisdictions the option to participate in immigration enforcement with two types of agreements: Task Force Enforcement (TF) allowed state and local law enforcement to screen for immigration status during regular policing operations (street screening) and Jail Enforcement (JE) allowed screening for immigration status in jails. The Secure Communities program required matching fingerprinting of all arrested individuals with the Immigration and Customs Enforcement (ICE) database to screen for immigration violations. We take advantage of the geographic (county-level) and temporal variations in the implementation of these policies. The empirical analysis is based on the restricted-use National Health Interview Survey (NHIS) (20002012) that provides information on health and mental health conditions as well as county- and state-level identifiers to match policy variables to the individual-level health and demographic data.

We adopt a difference-in-difference research design to control for unobserved timevarying factors correlated with county/state level enforcement policies. This methodology requires selection of treatment and comparison groups. The treatment group of our analyses is: foreign-born Latino adults living in families with at least one non-citizen family member. Due to the high probability of the presence of undocumented persons in these families, this group is 
likely to be highly vulnerable to local enforcement policies. We also experiment with a narrower treatment group that has an even heightened risk of having undocumented family members and therefore higher vulnerability to local enforcement: non-citizen Latino adults living in families with only non-citizen family members. The comparison group of the analysis is U.S. born nonHispanic white adults, whose members are unlikely to be affected by enforcement policies. The underlying assumption of the difference-in-difference design is that time-varying unobserved factors correlated with state/county enforcement policies have the same effect on the two groups. We obtain the difference-in-difference estimates by deducting the changes in outcomes for the comparison group before and after policy implementation, that capture the effect of unobserved time-varying factors, from the corresponding changes in outcomes for the treatment group. Additionally, our analyses control for a rich set of economic and policy variables, discussed in detail below, whose effects are allowed to be different across the treatment and comparison groups.

We find that the Secure Communities Program increased mental health distress among Latino immigrants living with non-citizen family members by 2.2 percentage points (14.7 percent), and Task Force Enforcement agreements under Section 287(g) deteriorated their mental health distress scores by 15 percent (or 0.08 standard deviation); Jail Enforcement under Section 287(g) increased the proportion of Latino immigrants reporting fair or poor health by 1 percentage point (11.1 percent) and lowered the proportion reporting very good or excellent health by 4.8 to 7.0 percentage points (7.8 to 10.9 percent). These findings remain robust across various sensitivity checks.

\section{LOCAL IMMIGRATION ENFORCEMENT POLICIES - SECTION 287(G) AND SECURE COMMUNITIES}


In 1996, with the ostensible goal to improve public safety and remove illegal immigrants who committed serious offenses, the Illegal Immigration Reform and Immigrant Responsibility Act, Section 287(g) granted state and local jurisdictions the option to participate in enforcing federal immigration laws. Localities opting to participate signed a Memorandum of Understanding with ICE that required establishing a supervisory structure to support localities and train local officials to enforce immigration laws. Local participation in Section 287(g) was negligible in the first decade after its passage. In 2002, Florida Department of Law Enforcement and in 2003 Alabama Department of Public Safety were the first two localities to sign 287(g) agreements with ICE. Local participation in 287(g) slowly picked up in 2005 and peaked in 2009, when the number of localities participating in the program rose to 76 . Twenty-four jurisdictions signed Task Force Enforcement (TF) agreements, 47 signed Jail Enforcement (JE) agreements, and 5 signed both TF and JE. Overall, TF agreements covered 22\% (690 out of 3140 counties) of the counties nationally, and JE agreements cover 3\% (106 counties) of all counties (Figure 1).

Interior immigration enforcement took another turn in 2008 with the launch of the Secure Communities Program (SC) that required the local police to match fingerprints of all arrested individuals with the ICE database to screen for immigration violations. Whereas Section 287(g) was designed to engage local law enforcement in immigration enforcement, Secure Communities allowed ICE a remote presence in local law enforcement agencies. Under SC, the state and local authorities were required to submit fingerprints of all arrested individuals to the Federal Bureau of Investigation (FBI), which the latter shared with ICE to check against immigration databases to identify (removable) undocumented individuals (ICE, 2015). Unlike Section 287(g), participation in Secure Communities was not voluntary. It was gradually rolled out across 
counties: beginning with 14 counties in 2008 to all counties nation-wide in 2013 (Figure 1). ${ }^{3}$ In response to public concerns about racial profiling, in 2012, TF was discontinued and in 2015, SC was replaced by the Priority Enforcement Program (PEP) that focuses on immigrants involved in organized criminal gangs or those that pose a danger to national security (ICE, 2016).

Previous research suggests that stricter local immigration controls reduced the economic opportunities of immigrants, lowering their employment, wages, and remittances (Kostandini, Mykerezi, \& Escalante, 2013; Pham \& Van, 2010; Gentsch \& Massey, 2011; Amuedo-Dorantes \& Puttitanun, 2013). The implementation of Section 287(g) was also associated with a decrease in claims against employers' discrimination based on national origin, indicating that enforcement policies had a "chilling effect” on vulnerable immigrants (Gleeson, 2014). Studies suggest that enforcement policies had a mixed impact on crime: Koper et al. (2013) found no effect in Prince William County, Virginia, whereas Donato \& Rodriquez (2014) reported a higher rate of police arrests on grounds of immigration status and national origin in Davidson County, Tennessee. Evidence is also mixed on the effect of local enforcement on migration patterns: Watson (2013) found that Task Force Enforcement policies increased the outflow of non-citizens with some college education, Ellis, Wright and Townley (2016) found that hostile immigration policies (e.g., local immigration enforcement policies, E-Verify, access to driver’s licenses) in a state reduced the inflow of non-citizen and naturalized Latinos in that state, whereas Parrado (2012) found that 287(g) did not affect the size of Mexican immigrant population in most localities except for large cities such as Dallas, Los Angeles, Riverside, and Phoenix, which registered a decline in the number of Mexican immigrants relative to other large cities without 287(g). In addition, research

\footnotetext{
${ }^{3}$ Some localities resisted the implementation of SC (Chen, 2016; Strunk \& Leitner, 2013), but such initiatives were not systematically and reliably documented for a national-level examination of their impacts. To the extent that such intentions are a permanent (time-invariant) feature of a locality (e.g., if a locality has a strong long term pro- or antiimmigrant environment), county fixed effects included in our analysis will control for it.
} 
suggests that local immigration enforcement increased Latino housing foreclosure rates (Rugh \& Hall, 2016) and food insecurity and poverty in vulnerable families with children (AmuedoDorantes, Arenas-Arroyo \& Sevilla, 2016, Potochnick, Chen, \& Perreira, 2016; Rugh \& Hall, 2016).

\section{IMMIGRATION ENFORCEMENT AND HEALTH}

Immigration is a stressful undertaking with negative psychosocial impacts (Vega \& Amaro, 1994; Jasso et al., 2004). It is associated with increased stress, fear, and uncertainty. For families with undocumented members, the negative health effects of migration are more intense and complicated (Sullivan \& Rehm, 2005; Delva et al., 2013). Repeated exposure to prejudice, discrimination, and exploitation on account of immigration status, and concerns about disclosure and deportation, of oneself or a family member, are likely to leave a negative impact on the physical as well as mental health of the undocumented and their family members (Vega \& Amaro, 1994; Cavazor-Rehg et al., 2007; Sullivan \& Rehm, 2005).

Immigration enforcement policies may affect health status of undocumented immigrants and their families in several ways. First, enforcement policies increase the risk of deportation and will likely to increase stress, fear, and anxiety among undocumented immigrants and their family members, which may adversely affect their health. Second, increased risk of deportation is likely to reduce economic opportunities of the undocumented and increase risk of workplace exploitation, which could in turn have negative health and mental health effects. Third, to minimize risk of deportation, the undocumented may reduce their time driving on the road, which may result in isolation and reduced social interaction and health service utilization (Rhodes et al., 2015; Hardy et al., 2011). Fourth, local enforcement may escalate immigrants’ levels of mistrust toward public institutions, further lowering their health and social service 
utilization (Watson, 2014; Padraza \& Zhu, 2015; Rhodes et al., 2015; Cavazos-Rehg, Zayas \& Spitznagel, 2007). Finally, to cope with the escalated psychological and economic burden associated with the increased risk and exploitation, immigrants may adopt certain unhealthy behaviors (e.g. smoking, alcohol consumption) leading to health deterioration. ${ }^{4}$

Most prior studies investigating the effects of local enforcement on health and mental health of immigrants were at a state- or local-level. Rhodes and colleagues (2015) study the impact of Section 287(g) on Hispanic immigrants in local counties in North Carolina; Hacker et al. (2011) study impacts of ICE activities in Everett, Massachusetts; Hardy et al. (2011) study the impact of the SB 1070 in Arizona, a bill that made failure to possess immigration documents a crime and expanded police power to detain potentially undocumented residents; and Lopez et al. (2016) study the impact of an immigration raid in the Washtenaw County, Michigan. The first three papers have used qualitative interviews and focus groups to study the effect of local enforcement. ${ }^{5}$ Respondents in these studies stated that they avoid using health care and other social services because of the threat of police enforcement while driving and their lack of trust in public institutions. They also reported delays in preventive services, incomplete sequence of care, reduced utilization of preventive and curative care, increased use of nonstandard and unsafe contingencies for care, and deterioration in mental health among family members.

Previous studies on the relationships between immigration enforcement and health did not specifically study the impact of 287(g) or Secure Communities policies. Lopez and colleagues (2016) used survey data collected before ( $\mathrm{n}=325)$ and after $(\mathrm{n}=151)$ an immigration

\footnotetext{
${ }^{4}$ These mechanisms closely mirror the framework through which Philbin and colleagues (2017) conceptualize how immigration-related policies may influence the health among Latinos.

${ }^{5}$ Rhodes and colleagues (2015) also used vital records data to quantitatively examine impacts of 287(g) on two measures of prenatal care: late entry into care and inadequate care. They found that 287(g) delayed Hispanic/Latina mothers to seek prenatal care and increased their likelihood to receive inadequate care compared to nonHispanic/Latina mothers. However, health and mental health impacts of 287(g) were only examined qualitatively through interviews and focus groups.
} 
raid and found that completing the survey after the raid was associated with lower self-rated health and higher stress. Hatzenbuehler et al. (2017) used 14 policies in the domains of immigration, race/ethnicity, language, and agricultural worker protections to create a policy climate index and used the Behavioral Risk Factor Surveillance System for 2012 to examine the association between the policy climate and immigrant mental health. Their research suggests that states that scored higher on the policy climate index, signifying a more exclusionary policy environment, were associated with poor mental health days in the past month among adults, and such association was stronger for Latinos. But this study is based on one year of data, because of which it is difficult to distinguish the effect of enforcement policies from those of unobserved state and county factors.

There is no national level study of the effect of local immigration enforcement on health and mental health of the undocumented and their family members. Ours is the first study to use national data. Secondly, studies on the relationships between immigration enforcement and health have mostly treated enforcement as a cluster of policies. We study the impact of specific dimensions of enforcement, namely: Task Force enforcement under 287(g), Jail Enforcement under 287 (g) and Secure Communities program. Finally, none of the existing studies used rigorous econometric models to identify the causal effects of local immigration enforcement on health and mental health of Latino immigrants, as we do in our paper.

This research is critical as negative health and mental health in immigrant communities has economic and fiscal consequences, including increased public health expenditures and reduced labor productivity (Brown et al., 2002; Martin et al., 2008; DeSalvo et al., 2009; Pirraglia et al., 2011; Bernard, Farr, \& Fang, 2011). Heightened health care costs along with the burden of poor health would adversely affect the wellbeing of immigrants in low-income 
neighborhoods and slow down their integration with the mainstream society. In this study, we take advantage of the "natural experiments" created by variations in the implementation of local immigration enforcement under Section 287(g) and Secure Community initiative across geographic locations (state and local jurisdictions) and time to study their effects on the health and mental health of the undocumented and their families.

\section{RESEARCH DESIGN}

Our objective is to study health impacts of local immigration enforcement on not only the undocumented immigrants, who are directly affected by local immigration enforcement, but also their family members who may be legal immigrants or U.S. citizens. The analysis is conducted on two samples of adults aged 18 to 60, born in Latin America (Latino immigrants hereafter): those in households with at least one non-citizen member (treat 1) and those in households with only non-citizen family members (and no citizens in the family; treat 2). We focus on these groups because 77 percent of all undocumented immigrants in the U.S. come from Latin America, with Mexico being the largest country of origin (56\% of all undocumented immigrants), followed by Guatemala (6\%), El Salvador (4\%), and Honduras (3\%) (Passel \& Cohn, 2011; Zong \& Batalova, 2016). Estimates show that $47 \%$ of foreign-born Latinos or $68 \%$ of non-citizen Latinos in the U.S. were undocumented in 2012 (U.S. Census Bureau, 2012; Zong \& Batalova, 2016). ${ }^{6}$ Restricting samples of analyses to Latino immigrants in households with at least one non-citizen or without any citizen (treatment groups hereafter) allows us to capture households most affected by the enforcement policies. We hypothesize that local immigration enforcement

\footnotetext{
${ }^{6}$ In 2012, the number of undocumented immigrants in the U.S. was estimated as 11.4 million, and $77 \%$ of them were from Latin America (Zong \& Batalova, 2016). This suggests that there were approximately 8.8 million Latino undocumented persons living in the U.S. $(11,400,000 \times 0.77=8,778,000)$. The number of foreign-born and noncitizen populations who identified as Latino in 2012 was 18,579,270 and 12,977,027, respectively (U.S. Census Bureau, 2012). Thus approximately $47 \%$ of foreign born Latinos $(8,778,000 / 18,579,270=0.47)$ or $68 \%$ of noncitizen Latinos $(8,778,000 / 12,977,027=0.68)$ in the U.S. were undocumented.
} 
policies adversely affect the health and mental health of Latino immigrants in households with at least one non-citizen, and effects will be even stronger for those living in households where all members are non-citizens, since they are more likely to be undocumented and hence have a higher risk of being directly affected by enforcement policies.

A primary challenge in any nation-wide study of the undocumented in the U.S. is that national data sources do not provide information on the legal status of foreign-born persons, so it is impossible to determine whether an immigrant respondent is an undocumented or legal resident. ${ }^{7}$ We try to address this limitation by identifying groups that have a high likelihood of being undocumented. We acknowledge that there may be some individuals in the treatment group/s that are unaffected by enforcement, which would result in estimates biased towards zero.

We begin with the following regression equation estimated separately on a sample of each of the treatment groups described above:

$H_{i c t}=\beta_{c}+\beta_{t}+\chi_{1} T F_{c t}+\chi_{2} J E_{c t}+\chi_{3} S C_{c t}+P_{c t} \varphi+X_{i c t} \Delta+u_{i c t}$,

$i=1, \ldots, \mathrm{N}$ (persons)

$c=1, \ldots$, C (counties)

$t=2000, \ldots, 2012$ (years)

where $H_{\text {ict }}$ represents a health outcome of individual $i$ (or a mental health outcome; described in detail in the Measures section); $T F_{c t}$ is coded as 1 if county $c$ has a Task Force Enforcement agreement with ICE in year $t$, otherwise $0 ; J E_{c t}$, equals to 1 if county $c$ has a Jail Enforcement agreement with ICE in year $t$, otherwise 0 ; and $S C_{c t}$ equals to 1 if county $c$ has a Secure Communities agreement in year $t$, otherwise 0 . The reference category for each of the three policy variables $-T F_{c t}, J E_{c t}$, and $S C_{c t}$ - is counties without the corresponding policy. The

\footnotetext{
${ }^{7}$ Researchers have explored strategies to impute legal status from survey data (Hall, Greeman, \& Farkas, 2010). The most suitable health data set for this study, NHIS, does not collect necessary information to replicate these imputation strategies.
} 
equation includes a full set of county fixed effects $\left(\beta_{c}\right)^{8}$ and year fixed effects $\left(\beta_{t}\right)$; time-varying county characteristics $\left(P_{c t}\right)$ namely county unemployment rate in year $t$, county poverty rate in year $t$, whether the county had applied for a 287(g) agreement with ICE in year $t$ or earlier that was denied or withdrawn, ${ }^{9}$ whether the county is located in a state that provides in-state tuition subsidy to undocumented residents in year $t$, whether the county is located in a state that allows undocumented immigrants to obtain a driver's license in year $t$, whether the county is located in a state that has implemented a policy in year $t$ under the Omnibus Bill regulations, ${ }^{10}$ and whether the county is located in a state that passed E-Verify in year $t ;{ }^{11}$ individual characteristics $\left(X_{i t}\right)^{12}$ namely age, sex, marital status, education level, household size, family income, citizenship status, years lived in the U.S., cohort of arrival, and country/region of origin; ${ }^{13}$ whether the interview

\footnotetext{
${ }^{8}$ Inclusion of county and year fixed effects allows the estimation of policy impacts within the same county after controlling for secular time-trends.

${ }^{9}$ More than one hundred unsuccessful 287(g) requests (denied or withdrawn) were filed by county, city or state governments. Requests for 287(g) agreements (withdrawn or denied) are indicative of a certain discriminatory environment towards the undocumented. Explicitly controlling for whether counties had requested to sign 287(g) with ICE in year t or earlier results in a cleaner comparison group. Additionally, including 287(g) requests as a policy category can explicitly estimate the effect of such discriminatory policy environment in the absence of policy implementation.

${ }^{10}$ Omnibus bills "require law enforcement to attempt to determine the immigration status of a person involved in a lawful stop; allow state residents to sue state and local agencies for noncompliance with immigration enforcement; require E-Verify; and make it a state violation for failure to carry an alien registration document (NCSL, 2012).” In some states, the Omnibus Bill regulations include policies forbidding undocumented immigrants to obtain driver's license or ID cards, policies that make it a felony for an undocumented immigrant to enter into business transactions with government, such as applying for or renewing a motor vehicle license plate or a business license, policies that make it illegal for a person to transport an immigrant; conceal, harbor or shield an undocumented immigrant, and policies denying public benefits to undocumented immigrants (NCSL, 2012).

${ }^{11}$ We acknowledge that there were also sanctuary localities across the U.S. County fixed effects included in our models can account for county-level time-invarying (during 2000 and 2012) hostile or friendly policy environment. We also conducted sensitivity analyses excluding sanctuary states from our analyses, and the results do not differ. ${ }^{12}$ The detailed coding of these controls are as follow: age ((omitted category 18-24), 25-29, 30-34, 35-39, 40-44, 4549, 50-54, 55-60), gender (male), marital status (married), education level (less than 9 years, 9-12 years (no high school degree), (omitted category: high school degree or GED), some colleges or more), household size (dummy variables indicating household size: 1, 2, (omitted category: 3-4), 5+), log family income, language of interview (not English), years since immigration (0-5, 6-10, 11-15, (omitted category: 15+)), cohort of arrival ((omitted category before 1987), 1987-1991, 1992-1996, 1997-2001, 2002-2012), citizenship status, and country/region of origin ((omitted category: Central America), Mexico, South America).

${ }^{13}$ In all analyses on Latino immigrants, we control for country/region of origin: Mexico, Central America, and South America.
} 
was conducted in English; and $u_{i c t}$ denotes the error term. Standard errors are clustered on county of residence.

One possible confounder in equation (1) is the presence of unobserved time-varying factors correlated with enforcement policies that would affect the health and mental health of Latino immigrants. For example, during the period of our study many states implemented policies (e.g., the Dream Acts, E-verify, Drivers' license, omnibus bills, etc.) that directly affected the wellbeing of undocumented immigrants. In addition, our study spans over a period of high economic instability, including the Great Recession. Previous studies find that the Great Recession lowered immigrants' employment more than that of the U.S. born population (Liu \& Edwards, 2015; Orrenius \& Zavodny, 2010). Evidence on health effect of the Great Recession is mixed ranging from negative to negligible to positive (Burgard, Ailshire, \& Kalousova, 2013; Tekin, McClellan, \& Minyard, 2013). While the implementation of Secure Communities coincided with the Great Recession, research suggests that the roll out schedule was not related to local economic conditions (Cox \& Miles, 2013).

To account for the influence of time-varying factors correlated with enforcement policies, equation (1) includes a rich set of time-varying county level factors $\left(P_{c t}\right)$, including county unemployment rate, poverty rate, and local policies that impacted immigrants. Further, we use a difference-in-difference (DD) research design, described in equation (2), to estimate enforcement policy effects over a combined sample of the treatment and comparison groups:

$H_{i c t}=\alpha_{c}+\alpha_{t}+\lambda_{1} T F_{c t}+\lambda_{2} J E_{c t}+\lambda_{3} S C_{c t}+\lambda_{r 1}\left(T r * T F_{c t}\right)+\lambda_{r 2}\left(T r * J E_{c t}\right)+$ $\lambda_{r 3}\left(\operatorname{Tr} * S E_{c t}\right)+\lambda_{r} * \operatorname{Tr}+P_{c t} \Phi+P_{c t} \operatorname{Tr} * \Phi+X_{i c t} \Gamma+e_{i c t}$ 
Tr is equal to 1 if the respondent belongs to the treatment group, otherwise $0 .{ }^{14}$ The differencein-difference coefficients, $\lambda_{r 1}, \lambda_{r 2}$, and $\lambda_{r 3}$, estimate the effects of Task force enforcement, Jail Enforcement and Secure Community Initiative, respectively, on the treatment group. Note that we allow the effect of time-varying factors to differ across the treatment and comparison groups by including interactions between the Treatment variable Tr and the vector denoting county-level time-varying factors $P_{c t} .{ }^{15}$ Our primary treatment group is: foreign-born Latino adults living in families with at least one non-citizen family member (treat 1) and comparison group is: U.S. born non-Hispanic white adults. We also experiment with a narrower treatment group of noncitizen Latino adults living in families with only non-citizen family members (treat 2), whose members have an even higher probability of being undocumented or have undocumented friends or family members than treat $1 .{ }^{16}$ The identifying assumption in equation (2) is that unobserved time-varying factors have the same effect on the outcome variables for the treatment and comparison groups. We conduct a number of tests to check the validity of the assumption and results are discussed in the section on sensitivity analysis.

A possible threat to our model specification could arise if the population most affected by local and state immigration enforcement decided to return to their countries of origin or relocated in another locality with a lesser threat of local enforcement. As indicated earlier, Watson (2013) found that while 287(g) did not result in voluntary emigration, Task Force enforcement increased the probability of relocating within the U.S. and the effect was greater among non-citizens with

\footnotetext{
${ }^{14}$ To control for the main effects of being Latino immigrant adults, instead of using one dummy variable, the empirical analysis includes years since immigration (0-5, 6-10, 11-15, 15+), cohort of arrival ((omitted category before 1987), 1987-1991, 1992-1996, 1997-2001, 2002-2012), citizenship status, and country/region of origin (Central America, Mexico, South America) in the analytic model. This way, we control for the heterogeneous composition of Latino immigrant adults. In treatment status' interactions with policy variables (or county-level timevarying characteristics), we use one single dummy variable for Latino immigrants adults to construct the interactions. ${ }^{15}$ We also experiment with models that include the interactions between $\operatorname{Tr}$ and $X_{i c t}$ (individual demographic factors), and findings are similar to our presented results.

${ }^{16}$ We also experimented with two additional comparison groups: U.S. born Hispanics and U.S. born non-Hispanic black adults, and results are discussed in the section on Sensitivity Analysis.
} 
at least some college education. On the other hand, Parrado (2012) found that 287(g) did not affect the size of Mexican immigrant population in most localities except for large cities such as Dallas, Los Angeles, Riverside, and Phoenix. There is not much we can do address this problem. In the event that immigrants who migrated out of a locality were the more privileged and healthier, our estimated policy effects would be upward biased. However, the out-migration of privileged fellow immigrants may weaken Latino communities and thus worsen health and mental health of the immigrants that are left behind. However, if those who decided to relocate were most adversely affected by policies, our estimated policy effects would be biased towards zero.

High non-response rates among the affected population constitute an additional source of bias. The NHIS asks respondents to provide their social security numbers (SSN). Although respondents could refuse and indeed more than $60 \%$ of Latino immigrants have done so (CarterPokras \& Fischer, 2010), this request may increase the probability of undocumented immigrants and their family members refusing to participate in the survey. Furthermore, the non-response patterns may be correlated with the policy variables. That is, the survey response rates could be lower among immigrants living in counties with immigration enforcement policies in the postpolicy period. Higher non-response among affected population is also likely to yield estimates that are biased towards zero, leading to a more conservative estimation or underestimation of the actual policy effects.

\section{DATA}

The empirical analysis requires merging the Section 287(g) and Secure Communities policy variables to the National Health Interview Survey (NHIS) data (2000-2012). NHIS is a nationally representative cross-sectional survey administered by the Centers for Disease Control 
and Prevention (CDC) that collect health-related information annually. NHIS adopts a stratified multistage sample design (CDC, 2017). Data on core health indicators (e.g. self-rated health) are collected from all household members. NHIS also includes a module on Sample Adult, in which one adult (aged 18 or more) is randomly selected from each family to answer additional questions (e.g., mental health distress questions) (CDC, 2017). Because of confidentiality and disclosure rules, the National Center for Health Statistics (NCHS) does not provide state/county level identifiers in the public use NHIS. Our analysis is based on the restricted-use NHIS that has state/county level identifiers. All data analyses were conducted at the New York Census Data Center upon approval from the NCHS Research Data Center, who also enabled merging of policy variables by county and year with the micro-level NHIS data. The restricted-use NHIS also provide detailed information on immigrants' year of entry in the U.S., which are used to construct control variables on the cohort of arrival and years since immigration.

The NHIS oversamples the Hispanic population, yielding a relatively large sample for our analyses. Because Latino immigrants cluster in a small number of counties in the U.S., the empirical analysis is based on 306 counties with at least 20 observations of Latino immigrants to avoid spurious results on account of a small number of observations in a few counties. ${ }^{17}$

Multiple sources have been used to compile data on the histories of policies and contextual economic environment. Data on local enforcement policies by county and year are from the ICE obtained through a FOIA request. The initiation dates of Secure Communities program are from publicly available ICE documents (ICE, 2013). The state Dream Act policy data are from various published papers (Kaushal, 2008; Kaushal \& Wang, 2016). Information on state policies relevant to undocumented immigrants such as eligibility to obtain driver's license,

\footnotetext{
${ }^{17}$ We also experimented with a higher cut-off - counties with at least 50 non-citizen Latino immigrants - and the results are similar (presented in Table 3).
} 
omnibus bills, and E-Verify is from the National Conference of State Legislatures (NCSL) websites (NCSL, 2012; NCSL, 2015a, 2015b). The county-level unemployment rates and poverty rates are from the Area Resource Files (released by Health Resources and Services Administration of the Department of Health and Human Services).

\section{MEASURES}

We study several dimensions of health and mental health of Latino immigrants (Table 1). Each individual in NHIS is asked to scale his/her subjective health status as excellent, very good, good, fair and poor, which we use to create two measures of self-reported health: Poor health is equal to 1 if a respondent reported their health as poor or fair, otherwise 0; Good health is equal 1 to if a respondent reported their health as very good or excellent, otherwise 0 . Self-rated health is considered a valid measure of overall health and mental health as it strongly predicts serious, chronic conditions, disability, health service utilization, mental illnesses as well as mortality (Goldstein, Siegel, \& Boyer, 1984; Burström \& Fredlund, 2001; Wu et al., 2013). It is also a reliable measure with a test-retest reliability similar to or better than those of many objective health condition questions (e.g., asthma, backache, and headaches/migraine) (Lundberg \& Manderbacka, 1996).

From each family in the NHIS, one sample adult (aged 18 or more) is randomly selected to answer questions, including those on respondent's mental health, in the survey's Sample Adult module. We used the following six questions to measure mental health: In the past 30 days, how often did you feel so sad so that nothing could cheer you up? In the past 30 days, how often did you feel nervous? In the past 30 days, how often did you feel restless and fidgety? In the past 30 days, how often did you feel hopeless? In the past 30 days, how often did you feel that everything was an effort? In the past 30 days, how often did you feel worthless? Respondents are 
asked to provide answers to these questions on a scale of 0 to 4 (none of the time, a little of the time, some of the time, most of the time, and all of the time). These six questions belong to the Kessler 6 (K6) scale (Kessler et al., 2002). We construct a measure (scale) of psychological distress based on these questions that ranges from 0 to 24, with a higher score representing worse mental health. The internal consistency of items in the scale is high (Cronbach's $\alpha=0.88$ ), indicating good reliability. We also recode the mental health score into a dichotomous measure: mental health distress ( 1 indicating respondent's mental health score is 6 or more, otherwise 0 ). This dichotomous measure of mental health distress is associated with higher levels of mental health care utilization, mental health impairment, substance use, sedentary behavior, and obesity (Prochaska et al., 2012).

\section{RESULTS}

Table 1 presents the demographic and health characteristics of adults, aged 18 to 60 , during 2000-2001, the pre-policy years covered by our analysis. We focus on two treatment groups: Latino immigrant adults in households with at least one non-citizen family member (treat 1) and Latino immigrant adults with only non-citizen (no citizen) family members (treat 2). While this second group of Latino immigrants has a higher probability of being undocumented or having undocumented family members, the restriction reduces the sample size, which may reduce our ability to detect small size effects, so we present descriptive statistics and findings for both groups. We also present the descriptive statistics of the comparison group, U.S. born nonHispanic White adults, whose members are unlikely to be affected by enforcement measures.

Latino immigrants in households with some or all non-citizen family members have a more disadvantageous socioeconomic status compared to U.S. born White adults. Over 77 percent Latino immigrant adults do not have college education compared to 36 percent U.S. born 
White adults. Latino immigrants are younger, more likely to be male, have larger household sizes but lower average incomes than the non-Hispanic White sample. Approximately two thirds of the Latino samples were interviewed in a language other than English, whereas almost all of the U.S. born non-Hispanic White adults were interviewed in English.

In respect to health outcomes, there are two main points to note. One, Latino immigrants are two to three percentage points (33 to 50\%) more likely to report fair to poor health and 10 to 13 percentage points (14 to 18\%) less likely to report excellent or very good health compared to U.S. born White adults. The difference in self-reported health could be a measure of the overall gap in health outcomes between these groups or it could simply be an indicator of the cultural difference in the manner in which these groups describe their health (Viruell-Fuentes et al., 2011). Two, the overall mental health of Latino immigrants is better than that of U.S. born White adults.

Table 2 presents the effect of local immigration enforcement policies on the health and mental health outcomes of Latino immigrants. The first three columns report findings from the first difference models based on equation (1) for the two treatment groups and the comparison group. All models control for age, gender, marital status, educational level, household size, log family income, county unemployment rate, county poverty rate, whether the state of residence has legislations related to undocumented immigrants (a dummy variable for each of the following policies: state Dream Act, driver's license, omnibus bills and E-Verify) in year t, as described in detail in the research methodology section and listed as notes to the Table, and county and year fixed effects. The foreign-born Latino samples further control for years since immigration, cohort of arrival, citizenship status, and region/country of origin. The last two columns present findings from the difference-in-difference (DD) models (equation 2) using a 
combined sample of treat 1 and comparison group (column 4) and treat 2 and comparison group (column 5). These models allow county/state-specific time-varying factors to differ for the treatment and comparison groups. The findings presented in the first three columns are coefficients from the policy variables, and the last two columns present coefficients from the interactions between the policy variables and the treatment status variable (treat 1 in column 4; treat 2 in column 5). While we present first difference results for the comparison group, for brevity we do not discuss those results, but simply note here that, as expected, in general the estimated effects of enforcement policies on the comparison group are modest and statistically insignificant (11 out of 12 reported coefficients in Table 2 for the comparison group are statistically insignificant).

Regressions in Table 2 are based on OLS models. ${ }^{18}$ Estimates in panel (1), column (1) suggest that SC increased the likelihoods of Latino immigrants in households with non-citizen members rating their overall health fair or poor by 1.4 to 2.7 percentage points (16 to 34 percent), and Task Force enforcement (TF) increased the likelihood of treat 2 reporting fair to poor health by 2.1 percentage points (26 percent), but had no statistically significant effect on treat 1 's probability of reporting poor/fair health. The difference-in-difference estimates that control for time-varying factors in a more parsimonious manner suggest that both Secure Communities (SC) and Jail Enforcement (JE) increased the probability of treat 1 reporting fair/poor health by 1 to 1.3 percentage points (11.1 to 14.4 percent). The difference-in-difference estimate of the effect of enforcement policies on treat 2 reporting poor/fair health was statistically insignificant. First stage estimates in panel (2) suggest that JE lowered Latino immigrants’ probability of reporting

\footnotetext{
${ }^{18}$ We also estimate dichotomous outcomes (poor health, good health, and mental health distress) using logistic regression models. Results are presented in Appendix Table $\mathrm{C}$ and are qualitatively the same as results from linear regression models. In addition, we present full results with all covariates (except for county and year fixed effects) in Appendix Table E.
} 
very good or excellent health by 3.4 to 7.1 percentage points (5.6 to 11.1 percent). The DD

estimates also show that JE lowered the probability of the treatment groups reporting excellent or very good health by 4.8 to 7.0 percentage points (7.9 to 10.9 percent).

Turning to the third outcome, mental health distress scores (higher values indicate higher levels of mental health distress), estimates show that TF increased the mental health score of treat 1 and treat 2 groups by 19.7 to 42.1 percent $(=0.429 / 2.18$ to $0.951 / 2.26)$, or 0.11 to 0.23 standard deviation, respectively. In the DD models, that allow controlling for unobserved timevarying factors, both SC and TF increased the mental health scores of the treatment groups by 9.8 to 14.8 percent, or 0.05 to 0.08 standard deviation. The point estimates for treat 2 are larger than those for treat 1 , but not always statistically significant.

Our fourth and last outcome is a dichotomized indicator of mental health distress (K6 mental health scale $\geq 6$ ). Estimates from the first difference model show that Task Force enforcement was associated with a 3 to 8 percentage points (20 to 53.3 percent) increase in prevalence of mental health distress among Latino immigrants. Estimates from the difference-indifference models indicate that SC increased the likelihood mental health distress by 2.2 to 3.2 percentage points (14.7 to 21.3 percent), and TF increased it by 2 to 3.5 percentage points (13.3 to 23.3 percent). ${ }^{19,20}$

\section{SENSITIVITY ANALYSIS}

\footnotetext{
${ }^{19} \mathrm{We}$ also estimated the effect of policy on severe mental distress (defined as Kessler 6 Scale: $\geq 12$ points). Only three percent of the two treatment groups and the comparison group report severe mental distress in our sample. Estimates from the first difference models suggest that TF increased the likelihood of severe mental health distress among treat 1 members, but we find no effects in difference-in-difference models.

${ }^{20}$ Prior studies have shown that stress suppresses the immune system and gets manifested in illnesses (Salleh, 2008). Chronic stress is also related to asthma, back pain, and migraine headaches (Salleh, 2008). Following previous research, we examine impacts of local immigration enforcement policies on a range of physical health conditions (Appendix Table D). Results from the DD models suggested that overall no effect on physical health conditions except in two cases: TF increased likelihoods of back or neck pain, and JE decreased the likelihood of asthma. The latter finding is contrary to our hypothesis. Lack of any effect for the other outcomes might suggest that it takes a longer time for heightened degree of stress to manifest on physical health outcomes.
} 
We conduct a number of sensitivity checks to investigate the robustness of our findings. The results from these analyses are presented in Table 3. For brevity, we present only the difference-in-difference estimates with treat 1 as the treatment group ${ }^{21}$ (same model as column 4 in Table 2). First, to reduce the influence of immigration patterns that may be correlated with enforcement policies (e.g., new immigrants being more selective on health than immigrants who arrived in the U.S. before enforcement policies were enacted), we restricted the analyses to respondents who arrived before 2002, which is before any jurisdiction adopted local immigration enforcement policies (columns 1). Second, we checked whether employing a stricter county inclusion criterion (having 50 or more Latino non-citizens in each county instead of 20) affected the results of our analyses (column 2). Third, we restricted our analyses to counties that were surveyed across all years (denoted as the balanced sample) to examine if our findings were affected by unbalanced panels across years (column 3). ${ }^{22}$ Our balanced panel of counties included about $70 \%$ of the original sample.

In columns 4 and 5, we conduct additional sensitivity analyses to address the concern that other unobserved time-varying factors correlated with the policy adoption may bias our results. Findings from prior studies showed that the adoption of 287(g) and Secure Communities policies was not random. For example, counties that experienced high level and growth in Hispanic population were more likely to pass 287(g) and Secure Communities policies (Cox \& Miles, 2013; Creek \& Yoder, 2012; Wong, 2012; Walker \& Leitner, 2011). In column 4, we restrict the sample of analysis to counties with density of people with Hispanic ethnicity in 2001 being more than the national average (similar to the approach adopted by Potochnick, Chen, \& Perreira,

\footnotetext{
${ }^{21}$ Many of the tests involve further restrictions of the analytic sample. Therefore, we present results from the larger of the treatment groups (Treat 1 ).

${ }^{22}$ NHIS regularly adjusts its sampling plan according to updated information from the recent Census. The redesign during the study period (2000-2012) happened in 2006. Some counties were a part of NHIS samples prior to 2006 but not after, and some counties were sampled by NHIS after but not prior to 2006.
} 
2016). This allows us to compare counties with relatively similar levels of Hispanic population prior to policy adoption. In column 5, we restrict the analyses to counties that have either adopted or requested to form a 287(g) agreement with ICE. Arguably, counties with more hostile political attitudes toward immigrants are more likely to apply to ICE for local immigration enforcement, and this contextual environment may affect immigrants' health and mental health. Excluding counties that have not initiated a 287(g) agreement allows us to compare counties with similar political environment towards undocumented immigrants (Potochnick, Chen, \& Perreira, 2016). Further, we also estimate models that do not include any control for the 287(g) request (column 6).

One criticism of our models is that secular trends in health outcomes of the treatment groups during the 2000s may be confounding the enforcement policy estimates. In column 7 , we present estimates from a model that further control for these trends by including a full set of year effects interacted with the treatment group. We also experimented with two other treatment groups. In column 8 the treatment group is Mexican non-citizen adults and in column 9 the treatment group is Latino non-citizen adults.

Overall, a number of findings remain robust across various models. One, JE reduced the proportion of Latino immigrants reporting very good/excellent health by 3.9 to 5.0 percentage points in all 9 models. Two, JE increased the proportion of Latino immigrants reporting fair/poor health by 0.5 to 1.2 percentage points, with the estimates being statistically insignificant in some models. Three, SC increased mental health distress (based on a dichotomized measure) among Latino immigrants by 0.4 to 2.6 percentage points with the effects being statistically significant in 7 out of 9 models; and TF deteriorated mental health scores of Latino immigrants by 0.01 to 18.0 percent with the effects being statistically significant in 7 out of 9 models. 
A number of previous studies that distinguished between county- and city-level enforcement policies versus state-level policies found that city- or county-level policies has stronger effects (Amuedo-Dorantes, Arenas-Arroyo \& Sevilla, 2016; Watson, 2013). Next, we investigate, whether health effects of enforcement measures are also more pronounced when the policy is enforced by only the city/county government compared to a state-wide policy. The results from this analysis are presented in Table 4 and show that the adverse effect of countylevel JE policy on excellent/very good health was stronger than that of state-level JE policies. The estimated effects of state policies on other health outcomes were statistically the same as those of county level policies.

The identifying assumption in the difference-in-difference research design is that timevarying factors correlated with policy have the same effect on the treatment and comparison groups. We test the validity of this assumption by restricting the analytic samples to treat 1 and comparison group members living in counties that did not implement 287(g) policies, did not submit a 287(g) request and did not implement SC before $2011 .{ }^{23}$ We assume that a pseudo policy intervention in 2005 and estimate a difference-in-difference model for each outcome. The model controls for demographic variables, county-specific time-varying factors, county and year fixed effects, $\operatorname{Tr}$ (treat 1 variable), and the interaction between $\operatorname{Tr}$ and the pseudo policy variable (equals to 1 if the year is 2005 or later, otherwise 0). If our identifying assumption that unobserved time-varying factors affect the treatment and comparison groups similarly is valid, the coefficient on the interaction term between Tr and pseudo policy should be close to zero and statistically insignificant. We repeat this test on two other pseudo policy interventions: a pseudo

\footnotetext{
${ }^{23}$ In 2010, 890 counties have implemented the Secure Communities Program, and by 2011, 1,990 counties have adopted the Secure Communities Program. We control for Secure Communities policy in our model to account for policy changes that happen since 2011. We also conduct another set of analyses only examining trends between 2000 and 2010.
} 
policy in 2007 and another in 2008. We chose the years 2005, 2007 and 2008 for pseudo policy intervention because these are the years when increasing numbers of counties adopted enforcement policies. Results from these analyses, conducted on data for 2000-2012 (the timeframe of this study) and 2000-2010 (period prior to SC initiative in any of the selected counties) are presented in Appendix Table A. The coefficient on the interaction term between $\mathrm{Tr}$ and Pseudo policy in all cases is indeed modest and statistically insignificant, providing support for the validity to our identifying assumption.

In an additional specification, we use U.S. born Hispanics as the comparison group. ${ }^{24}$ The disadvantage of using U.S. born Hispanics as comparison is that on account of their appearance many are likely to be victims of local immigration enforcement. The advantage is that this group is similar to the treatment groups in that its members are likely to be similarly affected by many unobserved factors. Results, presented in Appendix Table B, also show that enforcement policies adversely affected the health and mental health of the treatment group. ${ }^{25}$

One additional concern is that the adoption of enforcement policies may be related to the prevalence of crime. Specifically, localities with higher crime rates may be more likely to request to for a 287 (g) agreement with ICE or may implement Secure Communities earlier, and the high crime prevalence may have impacts on health and mental health. Previous studies have failed to find any association between local crime rate and implementation of 287(g) or SC policy (Wong, 2012; Cox \& Miles, 2013). However, pre-existing law enforcement culture in counties may be correlated with the adoption of local enforcement policies; localities where law enforcement is biased towards minorities may be more likely to pursue 287(g) policy, making it more difficult to

\footnotetext{
${ }^{24}$ We also conducted the same pseudo policy tests reported in Appendix Table A using U.S. born non-Hispanic black adults or U.S. born Hispanic adults as the comparison group, and results show that these two are valid comparison groups.

${ }^{25}$ It is also worth noting in the first difference models that local immigration enforcement policies did not have spillover effects on the U.S. born Hispanic population.
} 
separate the effect of the local immigration enforcement from other law enforcement policies. To address these potential sources of bias, we conduct sensitivity analyses using U.S. born nonHispanic black adults as the comparison group, since this group is not directly affected by the local immigration enforcement policies but is more affected by the local police enforcement environment. Note that this comparison group is not ideal because U.S. born black adults may be affected by intensified law enforcement as a result of local immigration enforcement policies. Estimates are presented in Appendix Table B and suggest immigration enforcement has adverse effects on the self-rated health of Latino immigrants.

\section{CONCLUSION}

We investigate the health and mental health effects of local immigration enforcement policies, namely Task Force Enforcement (TF) and Jail Enforcement (JE) agreements under Section 287(g) of IIRAIRA and the Secure Communities (SC) Program, using the restricted-use National Health Interview Survey (NHIS) for 2000-2012. Ours is the first study that has used multiple years of nationally representative data to investigate causal effects of two major local immigration enforcement policies: Section 287(g) and Secure Communities initiative on health and mental health of Latino immigrants. Overall, we find evidence that various local immigration enforcement policies had negative impacts on health and mental health of Latino immigrant populations.

Specifically, we find that SC increased mental health distress among Latino immigrants living with non-citizen family members by 2.2 percentage points (14.7 percent), and TF reduced their mental health distress scores by 15 percent (or 0.08 standard deviation). We also find that JE increased the risk of Latino immigrants in households with non-citizen members rating their overall health as fair or poor by 1 percentage points (11.1 percent), and JE lowered their 
probability of reporting very good or excellent health by 4.8 to 7.0 percentage points (7.8 to 10.9 percent). We administered a series of sensitivity tests and found these estimates to be robust across various specifications.

Our findings suggest that local enforcement policies had negative health and mental health effects on Latino immigrants. Arguably, Task Force Enforcement is likely to have a more adverse effect on the health and mental health of the undocumented than Jail Enforcement or the Secure Communities initiative. Reports however suggest that communities do not have a very nuanced response to different local enforcement policies and that they are fearful of any local enforcement measure (National Immigration Law Center, 2011; National Immigration Project, 2010). Further, we do not have data on whether the respondent was jailed or otherwise directly came in contact with the local enforcement agencies. Therefore, we believe our results represent the average effects of policy on those who experienced local enforcement and those who were fearful of these policies.

Our findings of the effects of local immigration enforcement on health and mental health of Latino immigrants at the national level are consistent with those of previous state- or locallevel qualitative studies (Rhodes et al., 2015; Hacker et al., 2011; Hardy et al., 2011). Our contribution is that we use multiple years of national level data and adopt a rigorous methodology to investigate the causal effects of enforcement policies on the health and mental health of Latino immigrants. Ours is also the first study to comprehensively examine the effects of both section 287(g) and Secure Communities initiative. Our findings suggest that by adversely affecting the health and mental health of Latino immigrants, local immigration enforcement may eventually increase public healthcare expenditure. ${ }^{26}$ This is an unintended consequence that was

\footnotetext{
${ }^{26}$ The undocumented are eligible for Emergency Medicaid if the undocumented are in a Medicaid-eligible category (e.g., children, pregnant women, elderly, or persons with disability, etc) (DuBard \& Massing, 2007; Okie, 2007;
} 
not taken into account when these policies were designed. Further, the negative health and mental health effects may adversely impact the economic productivity of Latino families and their integration with the U.S. society.

Sommers, 2013). Additionally, hospitals in the US are required to provide emergency care regardless of income, insurance, or citizenship statuses (DuBard \& Massing, 2007; Okie, 2007). Arguably, lack of timely care would increase utilization of Emergency Medicaid by the undocumented and impose a public health burden on the society. 


\section{References}

Amuedo-Dorantes, C, \& Puttitanun, T. (2014). Remittances and immigration enforcement. IZA Journal of Migration, 3(6).

Amuedo-Dorantes, C., Arenas-Arroyo, E., \& Sevilla, A. (2016). Immigration Enforcement and Childhood Poverty in the United States. Retrieved from:

https://www.econstor.eu/bitstream/10419/145164/1/dp10030.pdf

Bernard, D. S., Farr, S. L., \& Fang, Z. (2011). National estimates of out-of-pocket health care expenditure burdens among nonelderly adults with cancer: 2001 to 2008. Journal of Clinical Oncology, 29(20), 2821-2826.

Brown, M. L., Riley, G. F., Schussler, N., \& Etzioni, R. (2002). Estimating health care costs related to cancer treatment from SEER-Medicare data. Medical Care, 40(8), IV-104.

Burgard, S. A., Ailshire, J. A., \& Kalousova, L. (2013). The great recession and health: people, populations, and disparities. The ANNALS of the American Academy of Political and Social Science, 650(1), 194-213.

Burström, B., \& Fredlund, P. (2001). Self rated health: Is it as good a predictor of subsequent mortality among adults in lower as well as in higher social classes? Journal of Epidemiology and Community Health, 55(11), 836-840.

Capps, R., Rosenblum, M. R., Rodriquez, C., \& Chishti, M. (2011). Delegation and Divergence: A Study of 287(g) State and Local Immigration Enforcement. Washington, DC: Migration Policy Institute Report.

Carter-Pokras, O., \& Fischer, A. H. (2010). Improvements in Latino Health Data. In AguirreMolina, M., Borrell, L. N., \& Vega, W. (2010). Health Issues in Latino Males: A Social and Structural Approach (pp. 53-65). Piscataway, NJ: Rutgers University Press.

Cavazos-Rehg, P. A., Zayas, L. H., \& Spitznagel, E. L. (2007). Legal Status, Emotional Wellbeing, and Subjective Health Status of Latino Immigrants. Journal of the National Medical Association, 99(10), 1126-1131.

Centers for Disease Control and Prevention (CDC). (2017). National Health Interview Survey. Retrieved: https://www.cdc.gov/nchs/nhis/

Chen, M. H. (2016). Trust in immigration enforcement: State noncooperation and sanctuary cities after Secure Communities. Chi.-Kent L. Rev., 91, 13-57.

Cox, A. B., \& Miles, T. J. (2013). Policing immigration. University of Chicago Law Review, 80, 87-136.

Creek, H. M., \& Yoder, S. (2012). With a little help from our Feds: Understanding state immigration enforcement policy adoption in American federalism. The Policy Studies Journal, 40(4), 674-697. 
Delva, J., Horner, P., Sanders, L., Martinez, R., Lopez, W. D., \& Doering-White, J. (2013). Mental health problems of children of undocumented parents in the United States: A hidden crisis. Journal of Community Positive Practices, 13(3), 25-35.

DeSalvo, K. B., Jones, T. M., Peabody, J., McDonald, J., Fihn, S., Fan, V., ... \& Muntner, P. (2009). Health care expenditure prediction with a single item, self-rated health measure. Medical Care, 47(4), 440-447.

Donato, K. M., \& Rodríguez, L. A. (2014). Police arrests in a time of uncertainty: The impact of 287(g) on arrests in a new immigrant gateway. American Behavioral Scientist.

DuBard, C. A., \& Massing, M. W. (2007). Trends in emergency Medicaid expenditures for recent and undocumented immigrants. JAMA, 297(10), 1085-1092.

Ellis, M., Wright, R., \& Townley, M. (2016). State-Scale Immigration Enforcement and Latino Interstate Migration in the United States. Annals of the American Association of Geographers, 106(4), 891-908.

Gentsch, K., \& Massey, D. S. (2011). Labor market outcomes for legal Mexican immigrants under the new regime of immigration enforcement. Social Science Quarterly, 92(3), 875893.

Gleeson, S. (2014). Brokering immigrant worker rights: An examination of local immigration control, administrative capacity and civil society. Journal of Ethnic and Migration Studies.

Goldstein, M. S., Siegel, J. M., \& Boyer, R. (1984). Predicting changes in perceived health status. American Journal of Public Health, 74(6), 611-614.

Hacker, K., Chu, J., Leung, C., Marra, R., Pirie, A., Brahimi, M., ... \& Marlin, R. P. (2011). The impact of immigration and customs enforcement on immigrant health: perceptions of immigrants in Everett, Massachusetts, USA. Social Science \& Medicine, 73(4), 586-594.

Hall, M., Greenman, E., \& Farkas, G. (2010). Legal status and wage disparities for Mexican immigrants. Social Forces, 89(2), 491-513.

Hatzenbuehler, M. L., Prins, S. J., Flake, M., Philbin, M., Frazer, M. S., Hagen, D., \& Hirsch, J. (2017). Immigration policies and mental health morbidity among Latinos: A state-level analysis. Social Science \& Medicine, 174, 169-178.

Hardy, L. J., Getrich, C. M., Quezada, J. C., Guay, A., Michalowski, R. J., \& Henley, E. (2012). A call for further research on the impact of state-level immigration policies on public health. American journal of public health, 102(7), 1250-1253.

ICE. (2016). Priority Enforcement Program. Retrieved from https://www.ice.gov/pep\#wcmsurvey-target-id

ICE. (2015). Secure Communities. Retrieved from https://www.ice.gov/secure-communities 
Immigration Custom Enforcement (ICE). (2013). Secure Communities Activated Jurisdictions (as of January 22, 2013). Washington, DC: ICE.

Jasso, G., Massey, D. S., Rosenzweig, M. R., \& Smith. J. P. (2004). Immigrant HealthSelectivity and Acculturation. In Critical Perspectives on Racial and Ethnic Differences in Health in Late Life. Washington DC: The National Academies Press.

Kaushal, N. (2008). In-state Tuition for the Undocumented: Education Effects on Mexican Young Adults. Journal of Policy Analysis and Management, 27(4), 771-792.

Kaushal, N., \& Wang, J. S-H. (2016). State Dream Acts and education, health and mental health of Mexican youth in the U.S. Unpublished Paper.

Kessler, R.C., Andrews, G., Colpe, L.J., Hiripi, E., Mroczek, D.K., Normand, S.-L.T., Walters, E.E., \& Zaslavsky, A. (2002). Short screening scales to monitor population prevalances and trends in nonspecific psychological distress. Psychological Medicine, 32(6), 959-976.

Kostandini, G., Mykerezi, E., \& Escalante, C. (2013). The impact of immigration enforcement on the U.S. farming sector. American Journal of Agricultural Economics.

Koper, C. S., Guterbock, T. M., Woods, D. J., Taylor, B., \& Carter, T. J. (2013). The Effects of Local Immigration Enforcement on Crime and Disorder. Criminology \& Public Policy, 12(2), 239-276.

Lacayo, A. E. (2010). The impact of Section 287(g) of the Immigration and Nationality Act on the Latino community. Washington, DC: National Council of La Raza.

Liu, C. Y., \& Edwards, J. (2015). Immigrant employment through the Great Recession: Individual characteristics and metropolitan contexts. The Social Science Journal, 52(3), 405-414.

Lopez, M. H., Minushkin, S. (2008). 2008 National Survey of Latinos: Hispniacs see their situation in U.S. deteriorating; Oppose key immigration enforcement measures. Washington, DC: Pew Hispanic Center.

Lundberg, O., \& Manderbacka, K. (1996). Assessing reliability of a measure of self-rated health. Scandinavian Journal of Public Health, 24(3), 218-224.

Martin, B. I., Deyo, R. A., Mirza, S. K., Turner, J. A., Comstock, B. A., Hollingworth, W., \& Sullivan, S. D. (2008). Expenditures and health status among adults with back and neck problems. JAMA, 299(6), 656-664.

Masterson, K. (2016, December, 22). Federal authorities are still arresting immigrants who aren't top priorities for deportation. Vermont Public Radio. Retrieved from: http://www.wbur.org/morningedition/2016/12/22/immigration-arrests 
National Conference of State Legislatures. (2012). State Omnibus Immigration Legislation and Legal Challenges. Retrieved from: http://www.ncsl.org/research/immigration/omnibusimmigration-legislation.aspx

National Conference of State Legislatures. (2015a). States offering driver's licenses to immigrants. Retrieved from: http://www.ncsl.org/research/immigration/states-offeringdriver-s-licenses-to-immigrants.aspx

National Conference of State Legislatures. (2015b). State E-Verify action. Retrieved from: http://www.ncsl.org/research/immigration/state-e-verify-action.aspx National Immigration Law Center. (2011). DHS Proposes Fantasy Remedies to Cure Fundamental Flaws in the Secure Communities Program. Retrieved: https://www.nilc.org/issues/immigration-enforcement/dhs-6-17-11-memos-qa-2011-07/

National Immigration Project. (2010). What is Secure Communities and how it affects you. Retrieved from: https://www.nationalimmigrationproject.org/PDFs/community/2011_general-scfactsheet.pdf

Okie, S. (2007). Immigrants and health care-at the intersection of two broken systems. New England Journal of Medicine, 357(6), 525-529.

Orrenius, P. M., \& Zavodny, M. (2010). Mexican immigrant employment outcomes over the business cycle. The American Economic Review, 100(2), 316-320.

Padraza, F. I., \& Zhu, L. (2015). Immigration Enforcement and the "Chilling Effect” on Latino Medicaid Enrollment. Retrieved: http://healthpolicyscholars.org/sites/healthpolicyscholars.org/files/pedrazazhu_medicaid. pdf

Parrado, E. A. (2012). Immigration enforcement policies, the economic recession, and the size of local Mexican immigrant populations. The Annals of the American Academy, 641, 16-37.

Passel, J. S., \& Cohn, D’Vera. (2011). Unauthorized immigrant population: national and state trends, 2010. Washington, DC: Pew Hispanic Center.

Pham, H., \& Van, P. H. (2010). The economic impact of local immigration regulation: an empirical analysis. Cardozo Law Review, 485, 687-720.

Philbin, M. M., Flake, M., Hatzenbuehler, M. L., \& Hirsch, J. S. (2017). State-level immigration and immigrant-focused policies as drivers of Latino health disparities in the United States. Social Science \& Medicine.

Pirraglia, P. A., Hampton, J. M., Rosen, A. B., \& Witt, W. P. (2011). Psychological distress and trends in healthcare expenditures and outpatient healthcare. The American Journal of Managed Care, 17(5), 319. 
Potochnick, S., Chen, J. H., \& Perreira, K. (2016). Local-Level Immigration Enforcement and Food Insecurity Risk among Hispanic Immigrant Families with Children: National-Level Evidence. Journal of Immigrant and Minority Health, 1-8.

Prochaska, J. J., Sung, H. Y., Max, W., Shi, Y., \& Ong, M. (2012). Validity study of the K6 scale as a measure of moderate mental distress based on mental health treatment need and utilization. International Journal of Methods in Psychiatric Research, 21(2), 88-97.

Rhodes, S. D., Mann, L., Simán, F. M., Song, E., Alonzo, J., Downs, M., Lawlor, E., Martinez, O., Sun, C. J., O’Brien, M. C., Reboussin, B. A., \& Hall, M. A. (2015). The impact of local immigration enforcement policies on the health of immigrant hispanics/latinos in the United States. American Journal of Public Health, 105(2), 329-337.

Rugh, J. S., \& Hall, M. (2016). Deporting the American Dream: Immigration Enforcement and Latino Foreclosures. Sociological Science, 3, 1053-1076.

Salleh, M. R. (2008). Life event, stress and illness. Malaysian Journal of Medical Sciences, 15(4), 9-18.Sommers, B. D. (2013). Stuck between health and immigration reform—care for undocumented immigrants. New England Journal of Medicine, 369(7), 593-595.

Strunk, C., \& Leitner, H. (2013). Resisting federal-local immigration enforcement partnerships: Redefining 'Secure Communities’ and public safety. Territory, Politics, Governance, 1(1), 62-85.

Sullivan, M. M., \& Rehm, R. (2005). Mental health of undocumented Mexican immigrants: a review of the literature. Advances in Nursing Science, 28(3), 240-251.

Tekin, E., McClellan, C., \& Minyard, K. J. (2013). Health and health behaviors during the worst of times: evidence from the Great Recession (No. w19234). National Bureau of Economic Research.

US Census Bureau. (2016). American Fact Finder. Retrieved: http://factfinder.census.gov/faces/tableservices/jsf/pages/productview.xhtml?src=CF

Vaughan, J. M., \& Edwards, Jr., J. R. (2009). The 287(g) program: Protecting home towns and homeland. Washington, DC: Center for Immigration Studies.

Vega, W., \& Amaro, H. (1994). Latino outlook: Good health, uncertain prognosis. Annual Review of Public Health, 15, 39-67.

Viruell-Fuentes, E. A., Morenoff, J. D., Williams, D. R., \& House, J. S. (2011). Language of interview, self-rated health, and the other Latino health puzzle. American Journal of Public Health, 101(7), 1306-1313.

Walker, K. E., \& Leitner, H. (2011). The variegated landscape of local immigration policies in the United States. Urban Geography, 32(2), 156-178. 
Watson, T. (2013). Enforcement and immigrant location choice. NBER Working Paper 19626. Retrieved: http://www.nber.org/papers/w19626.pdf

Watson, T. (2014). Inside the Refrigerator: Immigration Enforcement and Chilling Effects in Medicaid Participation. American Economic Journal: Economic Policy, 6(3), 313-338.

Wong, T. K. (2012). 287(g) and the politics of interior immigration control in the United States: Explaining local cooperation with federal immigration authorities. Journal of Ethnic and Migration Studies, 38(5), 737-756.

Wu, S., Wang, R., Zhao, Y., Ma, X., Wu, M., Yan, X., \& He, J. (2013). The relationship between self-rated health and objective health status: a population-based study. BMC Public Health, 13(1), 1.

Zong, J., \& Batalova, J. (2016). Frequently Requested Statistics on Immigrants and Immigration in the United States. Washington, DC: Migration Policy Institute. Retrieved from: http://www.migrationpolicy.org/article/frequently-requested-statistics-immigrants-andimmigration-united-states\#Unauthorized Immigrants 
Table 1: Descriptive Statistics

\begin{tabular}{|c|c|c|c|}
\hline Indicators & $\begin{array}{c}\text { Treat 1: Foreign-born } \\
\text { Hispanic with at least } 1 \\
\text { non-citizen household } \\
\text { member }\end{array}$ & $\begin{array}{l}\text { Treat 2: Foreign-born } \\
\text { Hispanic with only non- } \\
\text { citizen household } \\
\text { members }\end{array}$ & $\begin{array}{l}\text { Comparison: U.S. born } \\
\text { Non-Hispanic White }\end{array}$ \\
\hline & Mean (S.D.) & Mean (S.D.) & Mean (S.D.) \\
\hline \multicolumn{4}{|l|}{ Demographic Characteristics } \\
\hline$\overline{\text { Age }}$ & $34.89(10.56)$ & $34.30(11.28)$ & 39.44 (11.47) \\
\hline Male & 0.52 & 0.60 & 0.49 \\
\hline Married & 0.65 & 0.48 & 0.61 \\
\hline \multicolumn{4}{|l|}{ Education } \\
\hline Less than 9 years & 0.37 & 0.38 & 0.01 \\
\hline 9-12 years (no degree) & 0.22 & 0.21 & 0.07 \\
\hline HS Degree or GED & 0.19 & 0.18 & 0.26 \\
\hline Some college or more & 0.18 & 0.17 & 0.64 \\
\hline Unknown & 0.05 & 0.05 & 0.02 \\
\hline \multicolumn{4}{|l|}{ Household Size } \\
\hline 1 person & 0.05 & 0.17 & 0.16 \\
\hline 2 people & 0.11 & 0.24 & 0.31 \\
\hline 3-4 people & 0.39 & 0.38 & 0.41 \\
\hline 5 or more people & 0.44 & 0.22 & 0.13 \\
\hline Family income (\$) & 43687 (34028) & 34684 (27409) & $88112(53402)$ \\
\hline $\begin{array}{l}\text { Interview Language - Not English } \\
\text { Health Outcomes }\end{array}$ & 0.60 & 0.67 & 0.00 \\
\hline Self-reported health (Fair/poor) & 0.09 & 0.08 & 0.06 \\
\hline Self-reported health (Excellent/very good) & 0.61 & 0.64 & 0.74 \\
\hline $\begin{array}{l}\text { Mental health scores (Range: } 0-24 \text {; higher values } \\
\text { indicating higher levels of mental health distress) }\end{array}$ & $2.18(3.92)$ & $2.26(4.17)$ & $2.58(3.79)$ \\
\hline $\begin{array}{l}\text { Mental health distress ( }=1 \text { if mental health score } \geq 6 \text {, } \\
\text { otherwise } 0 \text { ) }\end{array}$ & 0.15 & 0.15 & 0.16 \\
\hline Sample size for self-reported health outcomes & 71,241 & 18,948 & 172,185 \\
\hline Sample size for mental health outcomes & 24,210 & 7,680 & 75,090 \\
\hline
\end{tabular}

Note: Source: National Health Interview Survey 2000-2001 (NHIS). Samples consists of adults aged 18-60 living in counties with at least 20 non-citizen Hispanic observations in NHIS. Sample sizes correspond to the time period of 2000-2012. 
Table 2: Estimated Models for Self-Rated Health and Mental Health Distress (NHIS 2000-2012)

\begin{tabular}{|c|c|c|c|c|c|}
\hline \multirow[b]{2}{*}{ Sample } & \multicolumn{3}{|c|}{ First Difference } & \multicolumn{2}{|c|}{ Difference-in-difference } \\
\hline & Treat 1 & Treat 2 & Comparison & Treat 1 & Treat 2 \\
\hline Panel 1 & \multicolumn{5}{|c|}{ Fair/Poor Health } \\
\hline Secure Communities & $\begin{array}{l}0.014+ \\
(0.008)\end{array}$ & $\begin{array}{l}0.027+ \\
(0.014)\end{array}$ & $\begin{array}{l}-0.001 \\
(0.004)\end{array}$ & $\begin{array}{l}0.013+ \\
(0.007)\end{array}$ & $\begin{array}{l}0.015 \\
(0.012)\end{array}$ \\
\hline Task Force Enforcement & $\begin{array}{l}0.006 \\
(0.008)\end{array}$ & $\begin{array}{l}0.021+ \\
(0.012)\end{array}$ & $\begin{array}{l}-0.007+ \\
(0.004)\end{array}$ & $\begin{array}{l}0.007 \\
(0.008)\end{array}$ & $\begin{array}{l}0.015 \\
(0.010)\end{array}$ \\
\hline Jail Enforcement & $\begin{array}{l}0.004 \\
(0.008)\end{array}$ & $\begin{array}{l}0.015 \\
(0.012)\end{array}$ & $\begin{array}{l}-0.003 \\
(0.004)\end{array}$ & $\begin{array}{l}0.010^{*} \\
(0.005)\end{array}$ & $\begin{array}{l}0.007 \\
(0.010)\end{array}$ \\
\hline 287(g) request & $\begin{array}{l}0.012 \\
(0.008)\end{array}$ & $\begin{array}{l}0.018 \\
(0.014)\end{array}$ & $\begin{array}{l}0.005 \\
(0.004) \\
\end{array}$ & $\begin{array}{l}0.002 \\
(0.007) \\
\end{array}$ & $\begin{array}{l}-0.006 \\
(0.011) \\
\end{array}$ \\
\hline $\mathrm{N}$ & 71241 & 18948 & 172185 & 243426 & 191133 \\
\hline Panel 2 & \multicolumn{5}{|c|}{ Excellent/Very Good Health } \\
\hline Secure Communities & $\begin{array}{l}-0.016 \\
(0.022)\end{array}$ & $\begin{array}{l}0.009 \\
(0.034)\end{array}$ & $\begin{array}{l}-0.004 \\
(0.007)\end{array}$ & $\begin{array}{l}-0.016 \\
(0.017)\end{array}$ & $\begin{array}{l}0.005 \\
(0.026)\end{array}$ \\
\hline Task Force Enforcement & $\begin{array}{l}-0.042 \\
(0.032)\end{array}$ & $\begin{array}{l}-0.060 \\
(0.041)\end{array}$ & $\begin{array}{l}0.002 \\
(0.007)\end{array}$ & $\begin{array}{l}-0.010 \\
(0.022)\end{array}$ & $\begin{array}{l}-0.023 \\
(0.034)\end{array}$ \\
\hline Jail Enforcement & $\begin{array}{l}-0.034+ \\
(0.018)\end{array}$ & $\begin{array}{l}-0.071 * * \\
(0.024)\end{array}$ & $\begin{array}{l}0.007 \\
(0.009)\end{array}$ & $\begin{array}{l}-0.048^{*} \\
(0.020)\end{array}$ & $\begin{array}{l}-0.070^{* *} \\
(0.026)\end{array}$ \\
\hline $287(\mathrm{~g})$ requests & $\begin{array}{l}-0.039 * * \\
(0.014)\end{array}$ & $\begin{array}{l}-0.035 \\
(0.025)\end{array}$ & $\begin{array}{l}-0.010 \\
(0.007)\end{array}$ & $\begin{array}{l}0.004 \\
(0.014)\end{array}$ & $\begin{array}{l}0.027 \\
(0.022)\end{array}$ \\
\hline $\mathrm{N}$ & 71241 & 18948 & 172185 & 243426 & 191133 \\
\hline Panel 3 & \multicolumn{5}{|c|}{ Mental Health Distress Scores (the higher the worse) } \\
\hline Secure Communities & $\begin{array}{l}0.167 \\
(0.166)\end{array}$ & $\begin{array}{l}0.268 \\
(0.304)\end{array}$ & $\begin{array}{l}0.044 \\
(0.072)\end{array}$ & $\begin{array}{l}0.214+ \\
(0.128)\end{array}$ & $\begin{array}{l}0.334+ \\
(0.199)\end{array}$ \\
\hline Task Force Enforcement & $\begin{array}{l}0.429 * \\
(0.208)\end{array}$ & $\begin{array}{l}0.951^{* *} \\
(0.310)\end{array}$ & $\begin{array}{l}0.034 \\
(0.101)\end{array}$ & $\begin{array}{l}0.327+ \\
(0.174)\end{array}$ & $\begin{array}{l}0.436 \\
(0.286)\end{array}$ \\
\hline Jail Enforcement & $\begin{array}{l}-0.343 \\
(0.219)\end{array}$ & $\begin{array}{l}-0.397 \\
(0.274)\end{array}$ & $\begin{array}{l}-0.115 \\
(0.121)\end{array}$ & $\begin{array}{l}-0.194 \\
(0.177)\end{array}$ & $\begin{array}{l}-0.310 \\
(0.234)\end{array}$ \\
\hline 287(g) request & $\begin{array}{l}0.188 \\
(0.159)\end{array}$ & $\begin{array}{l}0.377+ \\
(0.228)\end{array}$ & $\begin{array}{l}0.072 \\
(0.077) \\
\end{array}$ & $\begin{array}{l}0.028 \\
(0.126)\end{array}$ & $\begin{array}{l}0.117 \\
(0.221)\end{array}$ \\
\hline $\mathrm{N}$ & 24210 & 7680 & 75090 & 99300 & 82770 \\
\hline Panel 4 & \multicolumn{5}{|c|}{ Mental Health Distress (Kessler 6 Scale $\geq 6$ points) } \\
\hline Secure Communities & $\begin{array}{l}0.008 \\
(0.014)\end{array}$ & $\begin{array}{l}0.010 \\
(0.026)\end{array}$ & $\begin{array}{l}0.003 \\
(0.007)\end{array}$ & $\begin{array}{l}0.022 * \\
(0.011)\end{array}$ & $\begin{array}{l}0.032+ \\
(0.017)\end{array}$ \\
\hline Task Force Enforcement & $\begin{array}{l}0.030 * \\
(0.015)\end{array}$ & $\begin{array}{l}0.080^{* *} \\
(0.026)\end{array}$ & $\begin{array}{l}0.003 \\
(0.009)\end{array}$ & $\begin{array}{l}0.020+ \\
(0.012)\end{array}$ & $\begin{array}{l}0.035+ \\
(0.020)\end{array}$ \\
\hline Jail Enforcement & $\begin{array}{l}-0.032+ \\
(0.018)\end{array}$ & $\begin{array}{l}-0.030 \\
(0.023)\end{array}$ & $\begin{array}{l}-0.012 \\
(0.008)\end{array}$ & $\begin{array}{l}-0.019 \\
(0.015)\end{array}$ & $\begin{array}{l}-0.022 \\
(0.020)\end{array}$ \\
\hline 287(g) requests & $\begin{array}{l}0.007 \\
(0.013)\end{array}$ & $\begin{array}{l}-0.004 \\
(0.020)\end{array}$ & $\begin{array}{l}0.005 \\
(0.007)\end{array}$ & $\begin{array}{l}-0.001 \\
(0.011)\end{array}$ & $\begin{array}{l}-0.004 \\
(0.019)\end{array}$ \\
\hline $\mathrm{N}$ & 24210 & 7680 & 75090 & 99300 & 82770 \\
\hline
\end{tabular}

Note: $+0.1>\mathrm{p} \geq 0.05,{ }^{*} 0.05>\mathrm{p} \geq 0.01,{ }^{* *} \mathrm{p}<0.01$. Each column for each outcome is based on a separate regression. The analysis is restricted to counties with at least 20 Latino non-citizen observations across survey years. The samples of analyses are adults aged 18-60 years. Treat 1 is foreign-born Hispanic with at least 1 non-citizen household member, treat 2 is foreign-born Hispanic with only non-citizen household members, and the comparison group is U.S. born NonHispanic white adults. In addition to the coefficients reported above, all models control for age ((omitted category 18-24), 25-29, 30-34, 35-39, 40-44, 45-49, 50-54, 55-60), gender (male), marital status (married), education level (less than 9 years, 9-12 years with no high school degree, (omitted category: high school degree or GED), some colleges or more, unknown), household size dummy variables (1, 2, (omitted category: 3-4), 5+), log family income, language of interview (not English), county unemployment rate, county poverty rate, whether the county of residence is in a state has legislations related to undocumented immigrants (Dream Act, driver's license, omnibus bills and E-Verify) in year $t$, and county and year fixed effects. The foreign born samples further control for years since immigration (0-5, 6-10, 11-15, (omitted category: 15+)), cohort of arrival ((omitted category before 1987), 1987-1991, 1992-1996, 1997-2001, 2002-2012), citizenship status, country/region of origin ((omitted category: Central America), Mexico, South America). In difference-in-difference models, we further include the interactions of the county-level variables (in italic above) and the treatment status (treat 1 or treat 2). The difference-in-difference estimates reported above (in the shaded area) are coefficients from the interactions of policy variables with the treatment status variable. Standard errors clustered on county of residence are in parenthesis. 


\section{Table 3: Sensitivity Analysis - Difference-in-difference estimates for Latino immigrants (NHIS 2000-2012)}

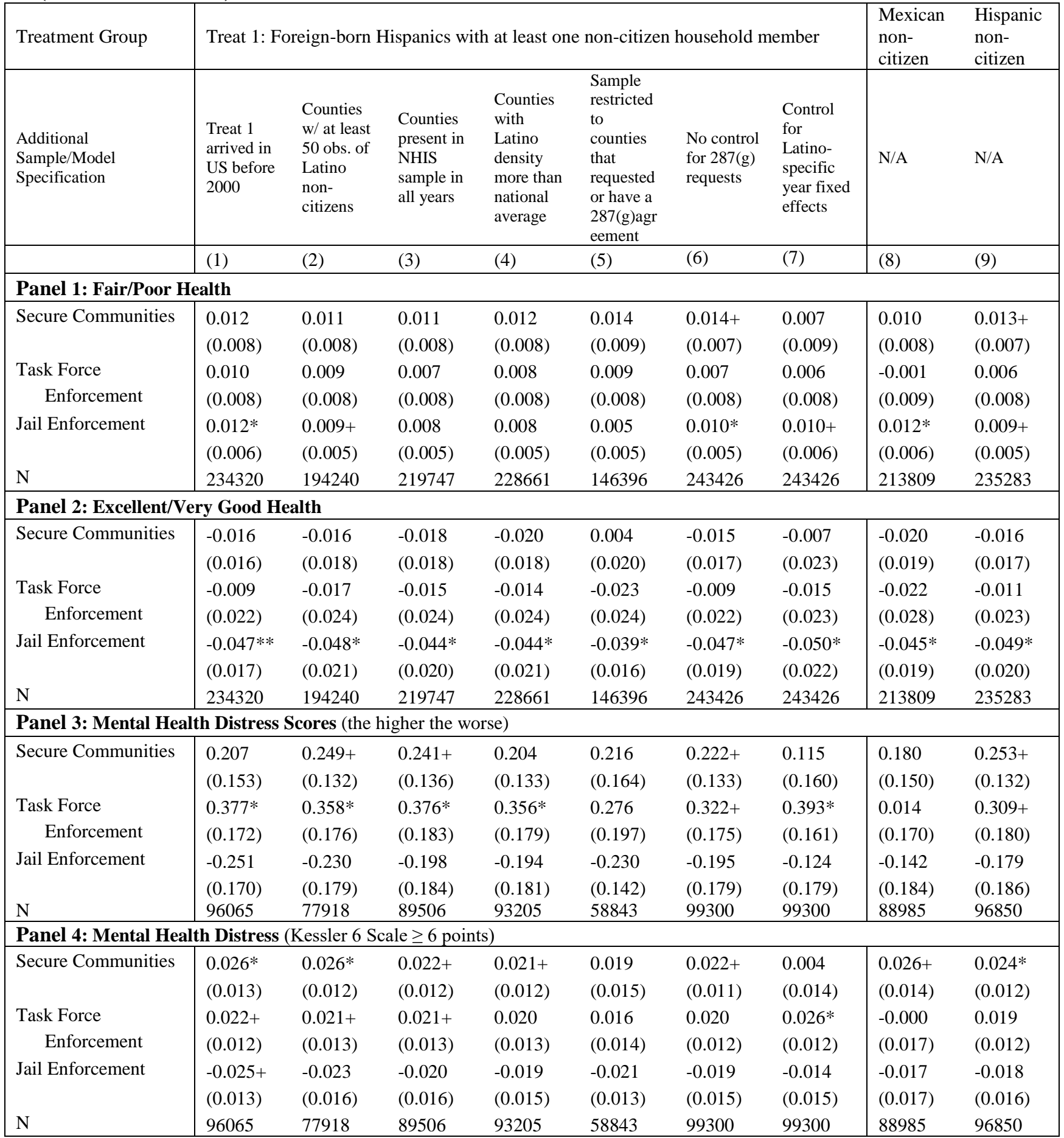

Note: $+0.1>\mathrm{p} \geq 0.05,{ }^{*} 0.05>\mathrm{p} \geq 0.01,{ }^{* *} \mathrm{p}<0.01$. Each column in each panel is based on a separate regression. All coefficients are from differencein-difference estimates. See Table 2 for model specifications. The treatment group (treat) is treat 1 in Table 2 (foreign-born Hispanic with at least 1 non-citizen household member) in all models except for (8) and (9), and the comparison group is U.S. born Non-Hispanic white adults in all models. All samples of analysis are adults aged 18-60 years. The analysis is restricted to counties with at least 20 Latino non-citizen observations across survey years. In model (1), the treatment sample is further restricted to those arrived to the U.S. before 2002. In model (2), we further restrict the analysis to counties with at least 50 Latino non-citizen observations across survey years. In model (3), we further restrict the analysis to counties that were in each year of the NHIS survey between 2000 and 2012. In model (4), we further restrict the analyses to counties that were in the top 50 percentile county in terms of the proportion of Hispanic population in 2001. In model (5), we further restrict the analysis to counties that have ever requested for or implemented a Section 287(g) policy (so the 287(g) request is not controlled in this model). In model (6), we do 
not include the control of "287(g) request” status. In model (7), we further control for the interactions between the Hispanic status (treatment status) and the year fixed effects to account for trends in the outcome that were unique to the treatment group population. In model (8), the treatment group is non-citizen adults born in Mexico. In model (9), the treatment group is Latino non-citizen adults. Standard errors clustered on county of residence are in parenthesis. 
Table 4: Estimated Difference-in-Difference Models - State versus Local Enforcement Policies (NHIS 2000-2012)

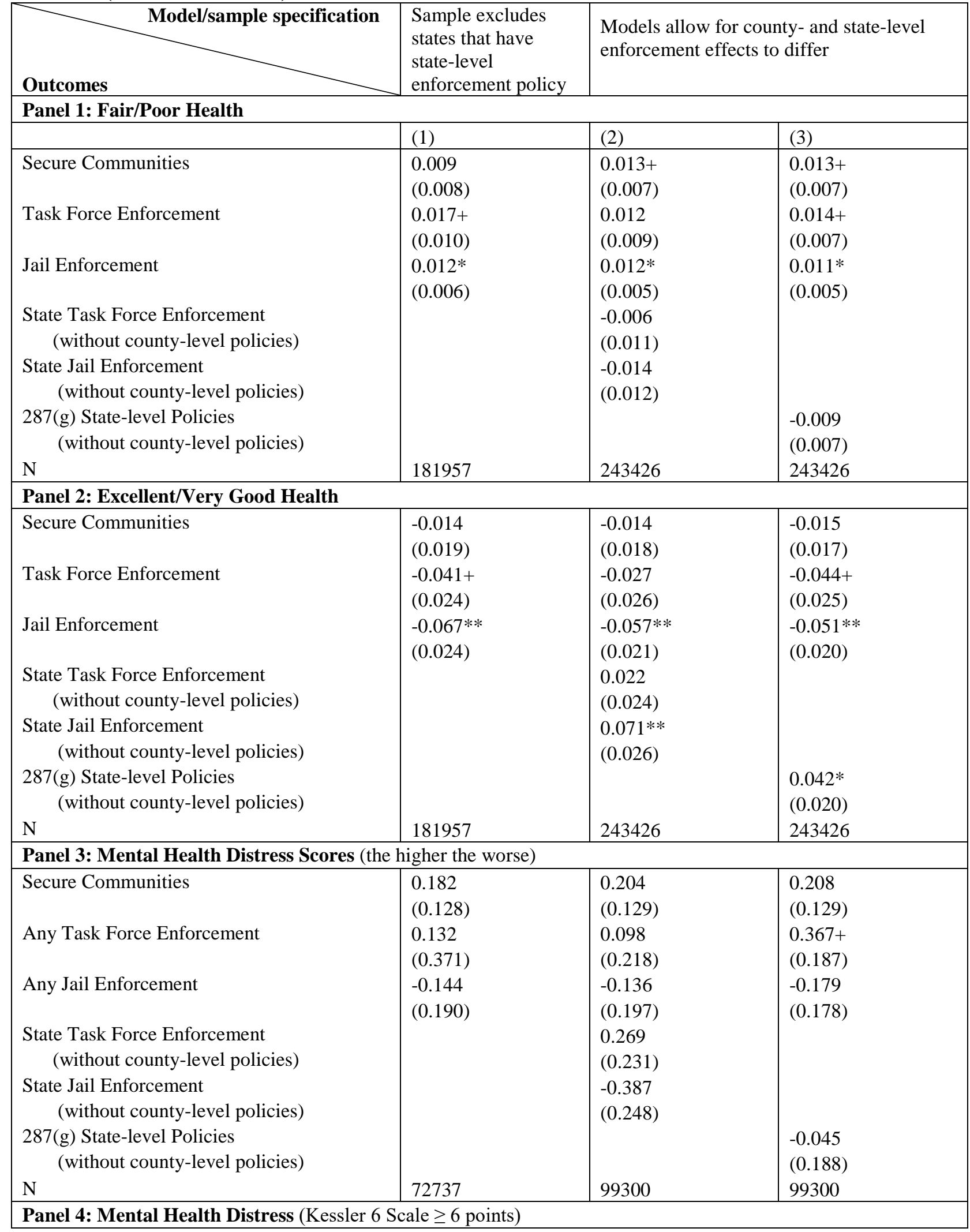




\begin{tabular}{|l|l|l|l|}
\hline Secure Communities & 0.019 & $0.022^{*}$ & $0.022^{*}$ \\
Any Task Force Enforcement & $(0.012)$ & $(0.011)$ & $(0.011)$ \\
& -0.004 & -0.001 & 0.021 \\
Any Jail Enforcement & $(0.034)$ & $(0.018)$ & $(0.016)$ \\
& -0.017 & -0.015 & -0.019 \\
State Task Force Enforcement & $(0.017)$ & $(0.017)$ & $(0.015)$ \\
$\quad$ (without county-level policies) & & 0.024 & \\
State Jail Enforcement & & $(0.021)$ & \\
$\quad$ (without county-level policies) & -0.029 & \\
287(g) State-level Policies & $(0.019)$ & -0.001 \\
$\quad$ (without county-level policies) & & & $(0.017)$ \\
$\mathrm{N}$ & 72737 & 99300 & 99300 \\
\hline
\end{tabular}

Note: $+0.1>\mathrm{p} \geq 0.05,{ }^{*} 0.05>\mathrm{p} \geq 0.01,{ }^{* *} \mathrm{p}<0.01$. Each column in each panel is based on a separate regression. All coefficients are from differencein-difference estimates. See Table 2 for model specifications. The treatment group (treat) is treat 1 in Table 2 (foreign-born Hispanic with at least 1 non-citizen household member) in all models, and the comparison group is U.S. born Non-Hispanic white adults in all models. All samples of analysis are adults aged 18-60 years. The analysis is restricted to counties with at least 20 Latino non-citizen observations across survey years. In panel (1), we exclude states that have ever had state-level 287(g) enforcement policies. In panel (2), we additionally control for two dummy variables, state-level TF and JE policies (where no county- or city-level policies was implemented), and their interactions with the treatment status (treat 1). In panel (3), we additionally control for one dummy variable, state-level 287(g) policies (collapsing TF and JE policies; where no county- or city-level policies was implemented) and its interaction with the treatment status (treat 1). 
500
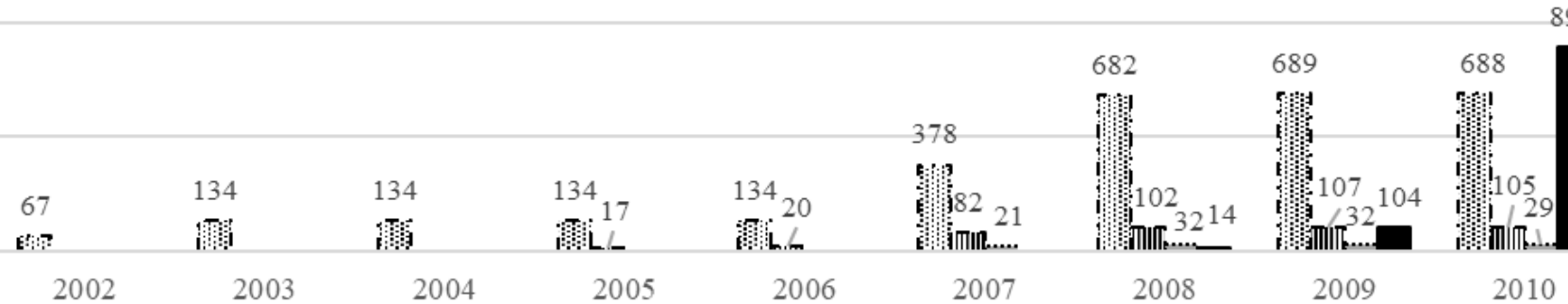

890

2002

2003

2004

2006

2007

2008

2009

2010

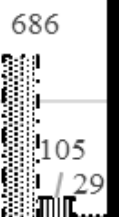

681

ITF II J

Note: SC: Secure Communities Program, TF: Task Force Enforcement, and JE: Jail Enforcement. The TF bars and the JE bars include counties that had both TF and JE agreements, "Both TF \& JE” bars separately show the number of counties that had both. Counties began implementing Task Force Enforcement in 2002, Jail Enforcement in 2005, and Secure Communities Program in 2008. The unit of analysis is county. 


\section{Appendix Table A: Association between Pseudo Policy and Outcomes - Difference-in-difference Models}

\begin{tabular}{|c|c|c|c|c|c|c|}
\hline \multirow{2}{*}{$\begin{array}{l}\text { Pseudo Policy Year } \\
\text { Years }\end{array}$} & \multicolumn{2}{|c|}{ Test 1: 2005} & \multicolumn{2}{|l|}{ Test 2: 2007} & \multicolumn{2}{|c|}{ Test 3: 2008} \\
\hline & $2000-2012$ & $2000-2010$ & $2000-2012$ & $2000-2010$ & $2000-2012$ & $2000-2010$ \\
\hline \multicolumn{7}{|c|}{ Panel 1: Fair/Poor Health } \\
\hline Pseudo policy X treat 1 & $\begin{array}{l}0.012 \\
(0.011)\end{array}$ & $\begin{array}{l}0.011 \\
(0.012)\end{array}$ & $\begin{array}{l}0.002 \\
(0.010)\end{array}$ & $\begin{array}{l}0.001 \\
(0.011)\end{array}$ & $\begin{array}{l}0.000 \\
(0.012)\end{array}$ & $\begin{array}{l}-0.003 \\
(0.012)\end{array}$ \\
\hline $\mathrm{N}$ & 58887 & 54450 & 58887 & 54450 & 58887 & 54450 \\
\hline \multicolumn{7}{|c|}{ Panel 2: Excellent/Very Good Health } \\
\hline Pseudo policy $\mathrm{X}$ treat 1 & $\begin{array}{l}-0.016 \\
(0.025) \\
\end{array}$ & $\begin{array}{l}-0.011 \\
(0.024)\end{array}$ & $\begin{array}{l}-0.001 \\
(0.021)\end{array}$ & $\begin{array}{l}0.008 \\
(0.020)\end{array}$ & $\begin{array}{l}0.009 \\
(0.027)\end{array}$ & $\begin{array}{l}0.021 \\
(0.028)\end{array}$ \\
\hline $\mathrm{N}$ & 58887 & 54450 & 58887 & 54450 & 58887 & 54450 \\
\hline \multicolumn{7}{|c|}{ Panel 3: Mental Health Distress Scores } \\
\hline Pseudo policy $\mathrm{X}$ treat 1 & $\begin{array}{l}-0.244 \\
(0.243)\end{array}$ & $\begin{array}{l}-0.237 \\
(0.251)\end{array}$ & $\begin{array}{l}-0.242 \\
(0.253)\end{array}$ & $\begin{array}{l}-0.278 \\
(0.263)\end{array}$ & $\begin{array}{l}-0.244 \\
(0.265)\end{array}$ & $\begin{array}{l}-0.333 \\
(0.281)\end{array}$ \\
\hline $\mathrm{N}$ & 24687 & 22866 & 24687 & 22866 & 24687 & 22866 \\
\hline \multicolumn{7}{|c|}{ Panel 4: Some Mental Health Distress } \\
\hline Pseudo policy X treat 1 & $\begin{array}{l}-0.021 \\
(0.021)\end{array}$ & $\begin{array}{l}-0.023 \\
(0.021) \\
\end{array}$ & $\begin{array}{l}-0.014 \\
(0.021)\end{array}$ & $\begin{array}{l}-0.021 \\
(0.022) \\
\end{array}$ & $\begin{array}{l}-0.004 \\
(0.022)\end{array}$ & $\begin{array}{l}-0.015 \\
(0.024)\end{array}$ \\
\hline $\mathrm{N}$ & 24687 & 22866 & 24687 & 22866 & 24687 & 22866 \\
\hline
\end{tabular}

Note: $+0.1>\mathrm{p} \geq 0.05,{ }^{*} 0.05>\mathrm{p} \geq 0.01,{ }^{* *} \mathrm{p}<0.01$. Models in each column and each panel are based on separate regressions using NHIS for 2000 2012 or 2000-2010, as specified in column sub-headings. The analysis is restricted to counties that have never requested or implemented an enforcement policy before 2011 (never submitted any 287(g) request, implemented a 287(g) agreement or Secure Communities Program before 2011). In addition, the analysis is restricted to counties with at least 20 Latino non-citizen observations across survey years. The samples of analyses are treat 1 , foreign-born Hispanic with at least 1 non-citizen household member, and the comparison group, U.S. born Non-Hispanic white adults. All samples are restricted to adults aged 18-60 years. For test 1: Pseudo policy is coded as 1 if the interview year was 2005 and after, otherwise 0; for test 2: Pseudo policy is coded as 1 if the interview year was 2007 and after, otherwise 0; for test 3: Pseudo policy is coded as 1 if the interview year was 2008 and after, otherwise 0 . All models control for demographic variables [age ((omitted category 18-24), 25-29, 30-34, 35-39, 40-44, 45-49, 50-54, 55-60), gender (male), marital status (married), education level (less than 9 years, 9-12 years with no high school degree, (omitted category: high school degree or GED), some colleges or more, unknown), household size dummy variables (1, 2, (omitted category: 3-4), 5+), log family income, language of interview (not English)], state-specific time-varying factors [county unemployment rate, county poverty rate, whether the county of residence is in a state has legislations related to undocumented immigrants (Secure Communities, Dream Act, driver's license, omnibus bills and E-Verify) in year t], treat 1 [years since immigration (0-5, 6-10, 11-15, (omitted category: 15+)), cohort of arrival ((omitted category before 1987), 1987-1991, 1992-1996, 1997-2001, 2002-2012), citizenship status, country/region of origin ((omitted category: Central America), Mexico, South America)], interactions of treat 1 and state-specific time-varying factors, the interactions of treat 1 with pseudo policy, and county and year fixed effects. Standard errors clustered on county of residence are in parenthesis. 
Appendix Table B: Estimated Models for Self-Rated Health and Mental Health Distress with Alternative Comparison Groups in Difference-in-Difference Models (NHIS 2000-2012)

\begin{tabular}{|c|c|c|c|c|c|c|}
\hline \multirow{2}{*}{$\begin{array}{l}\text { Comparison Groups } \\
\text { Treatment Groups } \\
\end{array}$} & \multicolumn{2}{|c|}{ U.S. born Hispanics } & \multicolumn{2}{|c|}{$\begin{array}{l}\text { U.S. born non-Hispanic } \\
\text { blacks }\end{array}$} & \multicolumn{2}{|c|}{$\begin{array}{l}\text { Foreign born non- } \\
\text { Hispanics Citizens }\end{array}$} \\
\hline & Treat 1 & Treat 2 & Treat 1 & Treat 2 & Treat 1 & Treat 2 \\
\hline \multicolumn{7}{|c|}{ Panel 1: Fair/Poor Health } \\
\hline $\begin{array}{l}\text { Secure Communities } \\
\text { (SC) }\end{array}$ & $\begin{array}{l}0.015+ \\
(0.009)\end{array}$ & $\begin{array}{l}0.014 \\
(0.012)\end{array}$ & $\begin{array}{l}-0.005 \\
(0.008)\end{array}$ & $\begin{array}{l}-0.003 \\
(0.012)\end{array}$ & $\begin{array}{l}0.004 \\
(0.010)\end{array}$ & $\begin{array}{l}0.013 \\
(0.013)\end{array}$ \\
\hline $\begin{array}{l}\text { Task Force } \\
\text { Enforcement (TF) }\end{array}$ & $\begin{array}{l}-0.002 \\
(0.010)\end{array}$ & $\begin{array}{l}0.005 \\
(0.012)\end{array}$ & $\begin{array}{l}0.012 \\
(0.009)\end{array}$ & $\begin{array}{l}0.014 \\
(0.011)\end{array}$ & $\begin{array}{l}0.011 \\
(0.007)\end{array}$ & $\begin{array}{l}0.021 * \\
(0.008)\end{array}$ \\
\hline Jail Enforcement (JE) & $\begin{array}{l}0.012 * \\
(0.005)\end{array}$ & $\begin{array}{l}0.007 \\
(0.010)\end{array}$ & $\begin{array}{l}0.027^{* *} \\
(0.009)\end{array}$ & $\begin{array}{l}0.023 \\
(0.015)\end{array}$ & $\begin{array}{l}0.009 \\
(0.009)\end{array}$ & $\begin{array}{l}0.006 \\
(0.014)\end{array}$ \\
\hline 287(g) request & $\begin{array}{l}-0.003 \\
(0.008)\end{array}$ & $\begin{array}{l}-0.006 \\
(0.010)\end{array}$ & $\begin{array}{l}-0.003 \\
(0.009)\end{array}$ & $\begin{array}{l}-0.006 \\
(0.012)\end{array}$ & $\begin{array}{l}0.004 \\
(0.009)\end{array}$ & $\begin{array}{l}-0.005 \\
(0.011)\end{array}$ \\
\hline $\mathrm{N}$ & 121155 & 68862 & 124532 & 72239 & 95368 & 44055 \\
\hline \multicolumn{7}{|c|}{ Panel 2: Excellent/Very Good Health } \\
\hline $\begin{array}{l}\text { Secure Communities } \\
\text { (SC) }\end{array}$ & $\begin{array}{l}-0.017 \\
(0.016)\end{array}$ & $\begin{array}{l}0.008 \\
(0.026)\end{array}$ & $\begin{array}{l}-0.007 \\
(0.018)\end{array}$ & $\begin{array}{l}0.011 \\
(0.027)\end{array}$ & $\begin{array}{l}0.004 \\
(0.021)\end{array}$ & $\begin{array}{l}0.022 \\
(0.025)\end{array}$ \\
\hline Task Force & -0.012 & -0.028 & -0.021 & -0.030 & 0.006 & -0.010 \\
\hline Enforcement (TF) & $(0.021)$ & $(0.028)$ & $(0.023)$ & $(0.036)$ & $(0.020)$ & $(0.028)$ \\
\hline Jail Enforcement (JE) & $\begin{array}{l}-0.049 * * \\
(0.011)\end{array}$ & $\begin{array}{l}-0.060 * * \\
(0.017)\end{array}$ & $\begin{array}{l}-0.072^{* *} \\
(0.014)\end{array}$ & $\begin{array}{l}-0.096 * * \\
(0.017)\end{array}$ & $\begin{array}{l}-0.037+ \\
(0.019)\end{array}$ & $\begin{array}{l}-0.061^{* *} \\
(0.023)\end{array}$ \\
\hline 287(g) request & $\begin{array}{l}-0.013 \\
(0.016)\end{array}$ & $\begin{array}{l}0.004 \\
(0.023)\end{array}$ & $\begin{array}{l}-0.007 \\
(0.015)\end{array}$ & $\begin{array}{l}0.013 \\
(0.021)\end{array}$ & $\begin{array}{l}-0.021 \\
(0.020)\end{array}$ & $\begin{array}{l}0.000 \\
(0.028)\end{array}$ \\
\hline $\mathrm{N}$ & 121155 & 68862 & 124532 & 72239 & 95368 & 44055 \\
\hline \multicolumn{7}{|c|}{ Panel 3: Mental Health Distress Scores (the higher the worse) } \\
\hline $\begin{array}{l}\text { Secure Communities } \\
\text { (SC) }\end{array}$ & $\begin{array}{l}0.185 \\
(0.148)\end{array}$ & $\begin{array}{l}0.352+ \\
(0.210)\end{array}$ & $\begin{array}{l}-0.252 \\
(0.163)\end{array}$ & $\begin{array}{l}-0.204 \\
(0.210)\end{array}$ & $\begin{array}{l}-0.006 \\
(0.153)\end{array}$ & $\begin{array}{l}0.125 \\
(0.203)\end{array}$ \\
\hline $\begin{array}{l}\text { Task Force } \\
\text { Enforcement (TF) }\end{array}$ & $\begin{array}{l}-0.066 \\
(0.239)\end{array}$ & $\begin{array}{l}-0.032 \\
(0.327)\end{array}$ & $\begin{array}{l}0.145 \\
(0.164)\end{array}$ & $\begin{array}{l}0.172 \\
(0.238)\end{array}$ & $\begin{array}{l}0.378 * * \\
(0.142)\end{array}$ & $\begin{array}{l}0.297+ \\
(0.170)\end{array}$ \\
\hline Jail Enforcement (JE) & $\begin{array}{l}-0.118 \\
(0.100)\end{array}$ & $\begin{array}{l}-0.209 \\
(0.170)\end{array}$ & $\begin{array}{l}-0.121 \\
(0.257)\end{array}$ & $\begin{array}{l}-0.314 \\
(0.312)\end{array}$ & $\begin{array}{l}-0.030 \\
(0.187)\end{array}$ & $\begin{array}{l}-0.108 \\
(0.259)\end{array}$ \\
\hline 287(g) request & $\begin{array}{l}-0.303^{*} \\
(0.128)\end{array}$ & $\begin{array}{l}-0.259 \\
(0.228)\end{array}$ & $\begin{array}{l}-0.118 \\
(0.188)\end{array}$ & $\begin{array}{l}-0.018 \\
(0.281)\end{array}$ & $\begin{array}{l}-0.018 \\
(0.176)\end{array}$ & $\begin{array}{l}0.055 \\
(0.245)\end{array}$ \\
\hline $\mathrm{N}$ & 42188 & 25658 & 48463 & 31933 & 32973 & 16739 \\
\hline \multicolumn{7}{|c|}{ Panel 4: Some Mental Health Distress (Kessler 6 Scale $\geq 6$ points) } \\
\hline $\begin{array}{l}\text { Secure Communities } \\
\text { (SC) }\end{array}$ & $\begin{array}{l}0.026^{*} \\
(0.013)\end{array}$ & $\begin{array}{l}0.040 * \\
(0.019)\end{array}$ & $\begin{array}{l}-0.003 \\
(0.015)\end{array}$ & $\begin{array}{l}0.005 \\
(0.019)\end{array}$ & $\begin{array}{l}-0.005 \\
(0.014)\end{array}$ & $\begin{array}{l}0.005 \\
(0.019)\end{array}$ \\
\hline $\begin{array}{l}\text { Task Force } \\
\text { Enforcement (TF) }\end{array}$ & $\begin{array}{l}0.001 \\
(0.018)\end{array}$ & $\begin{array}{l}0.010 \\
(0.026)\end{array}$ & $\begin{array}{l}0.010 \\
(0.012)\end{array}$ & $\begin{array}{l}0.017 \\
(0.019)\end{array}$ & $\begin{array}{l}0.017 \\
(0.013)\end{array}$ & $\begin{array}{l}0.021 \\
(0.017)\end{array}$ \\
\hline Jail Enforcement (JE) & $\begin{array}{l}-0.012 \\
(0.010)\end{array}$ & $\begin{array}{l}-0.015 \\
(0.015)\end{array}$ & $\begin{array}{l}-0.017 \\
(0.018)\end{array}$ & $\begin{array}{l}-0.027 \\
(0.023)\end{array}$ & $\begin{array}{l}-0.014 \\
(0.015)\end{array}$ & $\begin{array}{l}-0.016 \\
(0.022)\end{array}$ \\
\hline 287(g) request & $\begin{array}{l}-0.026 * \\
(0.012)\end{array}$ & $\begin{array}{l}-0.035+ \\
(0.020)\end{array}$ & $\begin{array}{l}-0.019 \\
(0.014)\end{array}$ & $\begin{array}{l}-0.026 \\
(0.021)\end{array}$ & $\begin{array}{l}-0.004 \\
(0.016)\end{array}$ & $\begin{array}{l}-0.013 \\
(0.022)\end{array}$ \\
\hline $\mathrm{N}$ & 42188 & 25658 & 48463 & 31933 & 32973 & 16739 \\
\hline
\end{tabular}

Note: $+0.1>\mathrm{p} \geq 0.05, * 0.05>\mathrm{p} \geq 0.01,{ }^{* *} \mathrm{p}<0.01$. See Table 2 for sample and model specifications. Treat 1 is foreign-born Hispanic with at least one non-citizen household member, treat 2 is foreign-born Hispanic with only non-citizen household members, and the comparison groups are U.S. born Hispanics and U.S. born Non-Hispanic black adults. The difference-in-difference estimates reported above are coefficients from the interactions of policy variables with the treatment status variable. 


\section{Appendix Table C: Estimated Models for Self-Rated Health and Mental Health Distress -}

Logistic Regression (NHIS 2000-2012)

\begin{tabular}{|c|c|c|c|c|c|}
\hline \multirow[b]{2}{*}{ Sample } & \multicolumn{3}{|c|}{ First Difference } & \multicolumn{2}{|c|}{ Difference-in-difference } \\
\hline & Treat 1 & Treat 2 & Comparison & Treat 1 & Treat 2 \\
\hline Panel 1 & \multicolumn{5}{|c|}{ Fair/Poor Health } \\
\hline Secure Communities & $\begin{array}{l}0.148 \\
(0.091)\end{array}$ & $\begin{array}{l}0.301+ \\
(0.163)\end{array}$ & $\begin{array}{l}0.004 \\
(0.056)\end{array}$ & $\begin{array}{l}0.114 \\
(0.080)\end{array}$ & $\begin{array}{l}0.145 \\
(0.142)\end{array}$ \\
\hline Task Force Enforcement & $\begin{array}{l}0.099 \\
(0.120)\end{array}$ & $\begin{array}{l}0.336+ \\
(0.197)\end{array}$ & $\begin{array}{l}-0.102+ \\
(0.062)\end{array}$ & $\begin{array}{l}0.043 \\
(0.115)\end{array}$ & $\begin{array}{l}0.155 \\
(0.148)\end{array}$ \\
\hline Jail Enforcement & $\begin{array}{l}0.018 \\
(0.088)\end{array}$ & $\begin{array}{l}0.138 \\
(0.154)\end{array}$ & $\begin{array}{l}-0.048 \\
(0.078)\end{array}$ & $\begin{array}{l}0.063 \\
(0.064)\end{array}$ & $\begin{array}{l}0.026 \\
(0.113)\end{array}$ \\
\hline 287(g) request & $\begin{array}{l}0.142 \\
(0.089)\end{array}$ & $\begin{array}{l}0.213 \\
(0.179)\end{array}$ & $\begin{array}{l}0.070 \\
(0.058)\end{array}$ & $\begin{array}{l}0.004 \\
(0.081)\end{array}$ & $\begin{array}{l}-0.097 \\
(0.139)\end{array}$ \\
\hline $\mathrm{N}$ & 70346 & 17834 & 172117 & 243426 & 191105 \\
\hline Panel 2 & \multicolumn{5}{|c|}{ Excellent/Very Good Health } \\
\hline Secure Communities & $\begin{array}{l}-0.069 \\
(0.097)\end{array}$ & $\begin{array}{l}0.050 \\
(0.155)\end{array}$ & $\begin{array}{l}-0.026 \\
(0.038)\end{array}$ & $\begin{array}{l}-0.071 \\
(0.078)\end{array}$ & $\begin{array}{l}0.025 \\
(0.122)\end{array}$ \\
\hline Task Force Enforcement & $\begin{array}{l}-0.217 \\
(0.153)\end{array}$ & $\begin{array}{l}-0.319 \\
(0.206)\end{array}$ & $\begin{array}{l}0.009 \\
(0.038)\end{array}$ & $\begin{array}{l}-0.037 \\
(0.103)\end{array}$ & $\begin{array}{l}-0.097 \\
(0.168)\end{array}$ \\
\hline Jail Enforcement & $\begin{array}{l}-0.147+ \\
(0.080)\end{array}$ & $\begin{array}{l}-0.325^{* *} \\
(0.108)\end{array}$ & $\begin{array}{l}0.035 \\
(0.051)\end{array}$ & $\begin{array}{l}-0.195 * \\
(0.087)\end{array}$ & $\begin{array}{l}-0.297 * \\
(0.116)\end{array}$ \\
\hline 287(g) requests & $\begin{array}{l}-0.172^{*} \\
(0.067) \\
\end{array}$ & $\begin{array}{l}-0.168 \\
(0.114) \\
\end{array}$ & $\begin{array}{l}-0.060 \\
(0.040) \\
\end{array}$ & $\begin{array}{l}0.037 \\
(0.061) \\
\end{array}$ & $\begin{array}{l}0.143 \\
(0.100) \\
\end{array}$ \\
\hline $\mathrm{N}$ & 71241 & 18751 & 172185 & 243426 & 191133 \\
\hline Panel 3 & \multicolumn{5}{|c|}{ Mental Health Distress (Kessler 6 Scale $\geq 6$ points) } \\
\hline Secure Communities & $\begin{array}{l}0.089 \\
(0.123)\end{array}$ & $\begin{array}{l}0.113 \\
(0.222)\end{array}$ & $\begin{array}{l}0.017 \\
(0.054)\end{array}$ & $\begin{array}{l}0.214^{*} \\
(0.094)\end{array}$ & $\begin{array}{l}0.299 * \\
(0.145)\end{array}$ \\
\hline Task Force Enforcement & $\begin{array}{l}0.316^{*} \\
(0.153)\end{array}$ & $\begin{array}{l}0.856^{* *} \\
(0.300)\end{array}$ & $\begin{array}{l}0.040 \\
(0.072)\end{array}$ & $\begin{array}{l}0.191+ \\
(0.112)\end{array}$ & $\begin{array}{l}0.327+ \\
(0.188)\end{array}$ \\
\hline Jail Enforcement & $\begin{array}{c}-0.278+ \\
(0.154)\end{array}$ & $\begin{array}{l}-0.281 \\
(0.206)\end{array}$ & $\begin{array}{l}-0.095 \\
(0.069)\end{array}$ & $\begin{array}{l}-0.186 \\
(0.139)\end{array}$ & $\begin{array}{l}-0.217 \\
(0.190)\end{array}$ \\
\hline $287(\mathrm{~g})$ requests & $\begin{array}{l}0.060 \\
(0.115)\end{array}$ & $\begin{array}{l}-0.022 \\
(0.183)\end{array}$ & $\begin{array}{l}0.031 \\
(0.056)\end{array}$ & $\begin{array}{l}-0.001 \\
(0.098)\end{array}$ & $\begin{array}{l}-0.033 \\
(0.166)\end{array}$ \\
\hline $\mathrm{N}$ & 23677 & 7085 & 75037 & 99300 & 82740 \\
\hline
\end{tabular}

Note: $+0.1>p \geq 0.05, * 0.05>p \geq 0.01, * * p<0.01$. Please see Table 2 for sample and model specifications. The difference-indifference estimates reported above (in the shaded area) are coefficients from the interactions of policy variables with the treatment status variable. 
Appendix Table D: Estimated Models for Physical Health Indicators (NHIS 2000-2012)

\begin{tabular}{|c|c|c|c|c|c|}
\hline & \multicolumn{3}{|c|}{ First Difference } & \multicolumn{2}{|c|}{ Difference in difference } \\
\hline Sample & Treat 1 & Treat 2 & Comparison & Treat 1 & Treat 2 \\
\hline Panel 1 & \multicolumn{5}{|c|}{ Had a cold in past 2 weeks } \\
\hline Secure Communities & $\begin{array}{l}0.019 \\
(0.012)\end{array}$ & $\begin{array}{l}0.013 \\
(0.022)\end{array}$ & $\begin{array}{l}0.007 \\
(0.007)\end{array}$ & $\begin{array}{l}0.010 \\
(0.010)\end{array}$ & $\begin{array}{l}0.005 \\
(0.017)\end{array}$ \\
\hline \multirow[t]{2}{*}{ Task Force Enforcement } & -0.001 & $0.029 *$ & 0.006 & 0.006 & 0.019 \\
\hline & $(0.011)$ & $(0.013)$ & $(0.008)$ & $(0.011)$ & $(0.014)$ \\
\hline \multirow[t]{2}{*}{ Jail Enforcement } & -0.005 & 0.007 & -0.012 & -0.002 & -0.007 \\
\hline & $(0.010)$ & $(0.013)$ & $(0.009)$ & $(0.010)$ & $(0.013)$ \\
\hline Panel 2 & \multicolumn{5}{|c|}{ Had sinusitis in the past 12 months (policy variables lagged by 1 year) } \\
\hline \multirow[t]{2}{*}{ Secure Communities } & 0.014 & -0.007 & -0.006 & 0.011 & 0.006 \\
\hline & $(0.009)$ & $(0.020)$ & $(0.009)$ & $(0.009)$ & $(0.013)$ \\
\hline \multirow[t]{2}{*}{ Task Force Enforcement } & 0.004 & 0.017 & 0.007 & 0.011 & 0.016 \\
\hline & $(0.009)$ & $(0.012)$ & $(0.010)$ & $(0.011)$ & $(0.010)$ \\
\hline \multirow[t]{2}{*}{ Jail Enforcement } & 0.005 & 0.023 & $0.013+$ & 0.004 & 0.020 \\
\hline & $(0.006)$ & $(0.014)$ & $(0.008)$ & $(0.009)$ & $(0.018)$ \\
\hline Panel 3 & \multicolumn{5}{|c|}{ Had back or neck pain in the past 3 months (policy variables lagged by 1 year) } \\
\hline \multirow[t]{2}{*}{ Secure Communities } & -0.001 & -0.060 & 0.001 & 0.012 & -0.032 \\
\hline & $(0.020)$ & $(0.044)$ & $(0.011)$ & $(0.013)$ & $(0.023)$ \\
\hline \multirow{2}{*}{ Task Force Enforcement } & $0.028+$ & 0.023 & -0.014 & $0.050 * *$ & $0.041 *$ \\
\hline & $(0.014)$ & $(0.021)$ & $(0.012)$ & $(0.013)$ & $(0.016)$ \\
\hline \multirow[t]{2}{*}{ Jail Enforcement } & -0.002 & 0.004 & 0.006 & -0.019 & -0.008 \\
\hline & $(0.015)$ & $(0.024)$ & $(0.011)$ & $(0.013)$ & $(0.019)$ \\
\hline Panel 4 & \multicolumn{5}{|c|}{ Had headache in the past $\mathbf{3}$ months (policy variables lagged by 1 year) } \\
\hline \multirow[t]{2}{*}{ Secure Communities } & -0.011 & $-0.040+$ & 0.000 & -0.002 & -0.003 \\
\hline & $(0.012)$ & $(0.022)$ & $(0.010)$ & $(0.010)$ & $(0.015)$ \\
\hline \multirow[t]{2}{*}{ Task Force Enforcement } & 0.012 & 0.016 & -0.009 & 0.019 & 0.025 \\
\hline & $(0.012)$ & $(0.015)$ & $(0.009)$ & $(0.012)$ & $(0.016)$ \\
\hline \multirow[t]{2}{*}{ Jail Enforcement } & 0.005 & 0.023 & 0.005 & -0.008 & 0.001 \\
\hline & $(0.009)$ & $(0.015)$ & $(0.007)$ & $(0.009)$ & $(0.014)$ \\
\hline Panel 5 & \multicolumn{5}{|c|}{ Had asthma in the past 12 months (policy variables lagged by 1 year) } \\
\hline \multirow[t]{2}{*}{ Secure Communities } & 0.004 & -0.008 & -0.003 & 0.003 & -0.003 \\
\hline & $(0.005)$ & $(0.011)$ & $(0.004)$ & $(0.005)$ & $(0.006)$ \\
\hline \multirow[t]{2}{*}{ Task Force Enforcement } & -0.003 & 0.003 & 0.002 & 0.002 & 0.004 \\
\hline & $(0.003)$ & $(0.005)$ & $(0.004)$ & $(0.004)$ & $(0.005)$ \\
\hline \multirow[t]{2}{*}{ Jail Enforcement } & -0.001 & -0.001 & 0.002 & -0.007 & $-0.008+$ \\
\hline & $(0.004)$ & $(0.004)$ & $(0.004)$ & $(0.005)$ & $(0.005)$ \\
\hline $\mathrm{N}$ & 24530 & 7811 & 76010 & 100540 & 83821 \\
\hline
\end{tabular}

Note: $+0.1>p \geq 0.05, * 0.05>p \geq 0.01,{ }^{* *} p<0.01$. See notes in Table 2 for sample and model specifications. The difference-indifference estimates reported above (in the shaded area) are coefficients from the interactions of policy variables with the treatment status variable. 


\section{Appendix Table E: Estimated Difference-in-Difference Models for Self-Rated Health and}

Mental Health Distress - All Covariates (NHIS 2000-2012)

\begin{tabular}{|c|c|c|c|c|c|c|c|c|}
\hline \multirow{2}{*}{ Treatment Group } & \multicolumn{2}{|c|}{ Fair/Poor Health } & \multicolumn{2}{|c|}{$\begin{array}{l}\text { Excellent/Very } \\
\text { Good Health }\end{array}$} & \multicolumn{2}{|c|}{$\begin{array}{l}\text { Mental Health } \\
\text { Distress Scores (the } \\
\text { higher the worse) }\end{array}$} & \multicolumn{2}{|c|}{$\begin{array}{l}\text { Mental Health } \\
\text { Distress (Kessler } 6 \\
\text { Scale } \geq 6 \text { points) } \\
\end{array}$} \\
\hline & Treat 1 & Treat 2 & Treat 1 & Treat 2 & Treat 1 & Treat 2 & Treat 1 & Treat 2 \\
\hline \multicolumn{9}{|l|}{ Policy Variables } \\
\hline Secure Communities (SC) & $\begin{array}{l}-0.002 \\
(0.004)\end{array}$ & $\begin{array}{l}-0.000 \\
(0.003)\end{array}$ & $\begin{array}{l}-0.000 \\
(0.008)\end{array}$ & $\begin{array}{l}-0.003 \\
(0.007)\end{array}$ & $\begin{array}{l}0.008 \\
(0.074)\end{array}$ & $\begin{array}{l}0.029 \\
(0.077)\end{array}$ & $\begin{array}{l}-0.003 \\
(0.007)\end{array}$ & $\begin{array}{l}0.000 \\
(0.007)\end{array}$ \\
\hline Task Force Enforcement & $\begin{array}{l}-0.004 \\
(0.004)\end{array}$ & $\begin{array}{l}-0.005 \\
(0.004)\end{array}$ & $\begin{array}{l}-0.008 \\
(0.008)\end{array}$ & $\begin{array}{l}-0.003 \\
(0.007)\end{array}$ & $\begin{array}{l}0.061 \\
(0.096)\end{array}$ & $\begin{array}{l}0.086 \\
(0.099)\end{array}$ & $\begin{array}{l}0.005 \\
(0.008)\end{array}$ & $\begin{array}{l}0.007 \\
(0.008)\end{array}$ \\
\hline Jail Enforcement & $\begin{array}{l}-0.003 \\
(0.005)\end{array}$ & $\begin{array}{l}-0.002 \\
(0.004)\end{array}$ & $\begin{array}{l}0.011 \\
(0.014)\end{array}$ & $\begin{array}{l}0.007 \\
(0.011)\end{array}$ & $\begin{array}{l}-0.134 \\
(0.122)\end{array}$ & $\begin{array}{l}-0.122 \\
(0.120)\end{array}$ & $\begin{array}{l}-0.013 \\
(0.009)\end{array}$ & $\begin{array}{l}-0.013 \\
(0.008)\end{array}$ \\
\hline 287(g) requests & $\begin{array}{l}0.005 \\
(0.004)\end{array}$ & $\begin{array}{l}0.005 \\
(0.004)\end{array}$ & $\begin{array}{l}-0.018+ \\
(0.009)\end{array}$ & $\begin{array}{l}-0.014+ \\
(0.008)\end{array}$ & $\begin{array}{l}0.077 \\
(0.076)\end{array}$ & $\begin{array}{l}0.071 \\
(0.077)\end{array}$ & $\begin{array}{l}0.005 \\
(0.007)\end{array}$ & $\begin{array}{l}0.004 \\
(0.007)\end{array}$ \\
\hline Treat X Secure Communities (SC) & $\begin{array}{l}0.013+ \\
(0.007)\end{array}$ & $\begin{array}{l}0.015 \\
(0.012)\end{array}$ & $\begin{array}{l}-0.016 \\
(0.017)\end{array}$ & $\begin{array}{l}0.005 \\
(0.026)\end{array}$ & $\begin{array}{l}0.214+ \\
(0.128)\end{array}$ & $\begin{array}{l}0.334+ \\
(0.199)\end{array}$ & $\begin{array}{l}0.022 * \\
(0.011)\end{array}$ & $\begin{array}{l}0.032+ \\
(0.017)\end{array}$ \\
\hline Treat X Task Force Enforcement & $\begin{array}{l}0.007 \\
(0.008)\end{array}$ & $\begin{array}{l}0.015 \\
(0.010)\end{array}$ & $\begin{array}{l}-0.010 \\
(0.022)\end{array}$ & $\begin{array}{l}-0.023 \\
(0.034)\end{array}$ & $\begin{array}{l}0.327+ \\
(0.174)\end{array}$ & $\begin{array}{l}0.436 \\
(0.286)\end{array}$ & $\begin{array}{l}0.020+ \\
(0.012)\end{array}$ & $\begin{array}{l}0.035+ \\
(0.020)\end{array}$ \\
\hline Treat X Jail Enforcement & $\begin{array}{l}0.010 * \\
(0.005)\end{array}$ & $\begin{array}{l}0.007 \\
(0.010)\end{array}$ & $\begin{array}{l}-0.048^{*} \\
(0.020)\end{array}$ & $\begin{array}{l}-0.070 * * \\
(0.026)\end{array}$ & $\begin{array}{l}-0.194 \\
(0.177)\end{array}$ & $\begin{array}{l}-0.310 \\
(0.234)\end{array}$ & $\begin{array}{l}-0.019 \\
(0.015)\end{array}$ & $\begin{array}{l}-0.022 \\
(0.020)\end{array}$ \\
\hline Treat X 287(g) requests & $\begin{array}{l}0.002 \\
(0.007)\end{array}$ & $\begin{array}{l}-0.006 \\
(0.011)\end{array}$ & $\begin{array}{l}0.004 \\
(0.014)\end{array}$ & $\begin{array}{l}0.027 \\
(0.022)\end{array}$ & $\begin{array}{l}0.028 \\
(0.126)\end{array}$ & $\begin{array}{l}0.117 \\
(0.221)\end{array}$ & $\begin{array}{l}-0.001 \\
(0.011)\end{array}$ & $\begin{array}{l}-0.004 \\
(0.019)\end{array}$ \\
\hline \multicolumn{9}{|l|}{ County Control Variables } \\
\hline Poverty rate & $\begin{array}{l}0.002 * * \\
(0.001)\end{array}$ & $\begin{array}{l}0.002 * * \\
(0.001)\end{array}$ & $\begin{array}{l}-0.004^{* *} \\
(0.001)\end{array}$ & $\begin{array}{c}-0.003 * \\
(0.001)\end{array}$ & $\begin{array}{l}0.023 \\
(0.016)\end{array}$ & $\begin{array}{l}0.020 \\
(0.016)\end{array}$ & $\begin{array}{l}0.001 \\
(0.001)\end{array}$ & $\begin{array}{l}0.001 \\
(0.001)\end{array}$ \\
\hline Unemployment rate & $\begin{array}{l}-0.001 \\
(0.001)\end{array}$ & $\begin{array}{l}-0.001 \\
(0.001)\end{array}$ & $\begin{array}{l}-0.001 \\
(0.003)\end{array}$ & $\begin{array}{l}-0.001 \\
(0.002)\end{array}$ & $\begin{array}{l}-0.006 \\
(0.020)\end{array}$ & $\begin{array}{l}-0.010 \\
(0.021)\end{array}$ & $\begin{array}{l}-0.001 \\
(0.002)\end{array}$ & $\begin{array}{l}-0.002 \\
(0.002)\end{array}$ \\
\hline Dream Act & $\begin{array}{l}-0.001 \\
(0.004)\end{array}$ & $\begin{array}{l}0.004 \\
(0.003)\end{array}$ & $\begin{array}{l}0.002 \\
(0.009)\end{array}$ & $\begin{array}{l}-0.010 \\
(0.007)\end{array}$ & $\begin{array}{l}0.189 * \\
(0.080)\end{array}$ & $\begin{array}{l}0.234^{* *} \\
(0.083)\end{array}$ & $\begin{array}{l}0.014 * \\
(0.007)\end{array}$ & $\begin{array}{l}0.018 * * \\
(0.007)\end{array}$ \\
\hline Driver's License & $\begin{array}{l}0.005 \\
(0.009)\end{array}$ & $\begin{array}{l}0.003 \\
(0.008)\end{array}$ & $\begin{array}{l}-0.014 \\
(0.021)\end{array}$ & $\begin{array}{l}-0.008 \\
(0.024)\end{array}$ & $\begin{array}{l}0.207 \\
(0.198)\end{array}$ & $\begin{array}{l}0.107 \\
(0.204)\end{array}$ & $\begin{array}{l}0.026+ \\
(0.015)\end{array}$ & $\begin{array}{l}0.021 \\
(0.016)\end{array}$ \\
\hline Omnibus bills & $\begin{array}{l}0.006 \\
(0.014)\end{array}$ & $\begin{array}{l}0.005 \\
(0.014)\end{array}$ & $\begin{array}{l}0.009 \\
(0.020)\end{array}$ & $\begin{array}{l}0.012 \\
(0.018)\end{array}$ & $\begin{array}{l}0.531^{*} \\
(0.232)\end{array}$ & $\begin{array}{l}0.552 * \\
(0.228)\end{array}$ & $\begin{array}{l}0.038+ \\
(0.020)\end{array}$ & $\begin{array}{l}0.040 * \\
(0.020)\end{array}$ \\
\hline E-Verify & $\begin{array}{l}0.006 * * \\
(0.002)\end{array}$ & $\begin{array}{l}0.006 * * \\
(0.002)\end{array}$ & $\begin{array}{l}-0.011^{*} \\
(0.004)\end{array}$ & $\begin{array}{l}-0.008 * \\
(0.004)\end{array}$ & $\begin{array}{l}0.063+ \\
(0.038)\end{array}$ & $\begin{array}{l}0.038 \\
(0.040)\end{array}$ & $\begin{array}{l}0.004 \\
(0.003)\end{array}$ & $\begin{array}{l}0.003 \\
(0.004)\end{array}$ \\
\hline Treat $\mathrm{X}$ Poverty rate & $\begin{array}{l}-0.001 * \\
(0.001)\end{array}$ & $\begin{array}{l}-0.001 \\
(0.001)\end{array}$ & $\begin{array}{l}0.002 \\
(0.002)\end{array}$ & $\begin{array}{l}0.001 \\
(0.002)\end{array}$ & $\begin{array}{l}-0.012 \\
(0.009)\end{array}$ & $\begin{array}{l}-0.005 \\
(0.014)\end{array}$ & $\begin{array}{l}-0.001 \\
(0.001)\end{array}$ & $\begin{array}{l}-0.001 \\
(0.001)\end{array}$ \\
\hline Treat X Unemployment rate & $\begin{array}{l}0.001 \\
(0.001)\end{array}$ & $\begin{array}{l}-0.000 \\
(0.002)\end{array}$ & $\begin{array}{l}0.000 \\
(0.002)\end{array}$ & $\begin{array}{l}-0.001 \\
(0.003)\end{array}$ & $\begin{array}{l}0.019 \\
(0.015)\end{array}$ & $\begin{array}{l}0.038 \\
(0.028)\end{array}$ & $\begin{array}{l}0.001 \\
(0.001)\end{array}$ & $\begin{array}{l}0.001 \\
(0.002)\end{array}$ \\
\hline Treat X Dream Act & $\begin{array}{l}0.016 * * \\
(0.005)\end{array}$ & $\begin{array}{l}0.028 * * \\
(0.008)\end{array}$ & $\begin{array}{l}-0.065^{* *} \\
(0.014)\end{array}$ & $\begin{array}{l}-0.080 * * \\
(0.025)\end{array}$ & $\begin{array}{l}-0.001 \\
(0.128)\end{array}$ & $\begin{array}{l}-0.069 \\
(0.216)\end{array}$ & $\begin{array}{l}0.004 \\
(0.010)\end{array}$ & $\begin{array}{l}0.007 \\
(0.017)\end{array}$ \\
\hline Treat X Driver's License & $\begin{array}{l}-0.007 \\
(0.008)\end{array}$ & $\begin{array}{l}0.001 \\
(0.021)\end{array}$ & $\begin{array}{l}0.035 \\
(0.027)\end{array}$ & $\begin{array}{l}0.044 \\
(0.045)\end{array}$ & $\begin{array}{l}0.384 \\
(0.287)\end{array}$ & $\begin{array}{l}0.146 \\
(0.423)\end{array}$ & $\begin{array}{l}0.031 \\
(0.022)\end{array}$ & $\begin{array}{l}-0.003 \\
(0.036)\end{array}$ \\
\hline Treat X Omnibus bills & -0.019 & 0.013 & $0.091^{* *}$ & 0.054 & -0.145 & $-1.289+$ & -0.009 & -0.064 \\
\hline
\end{tabular}




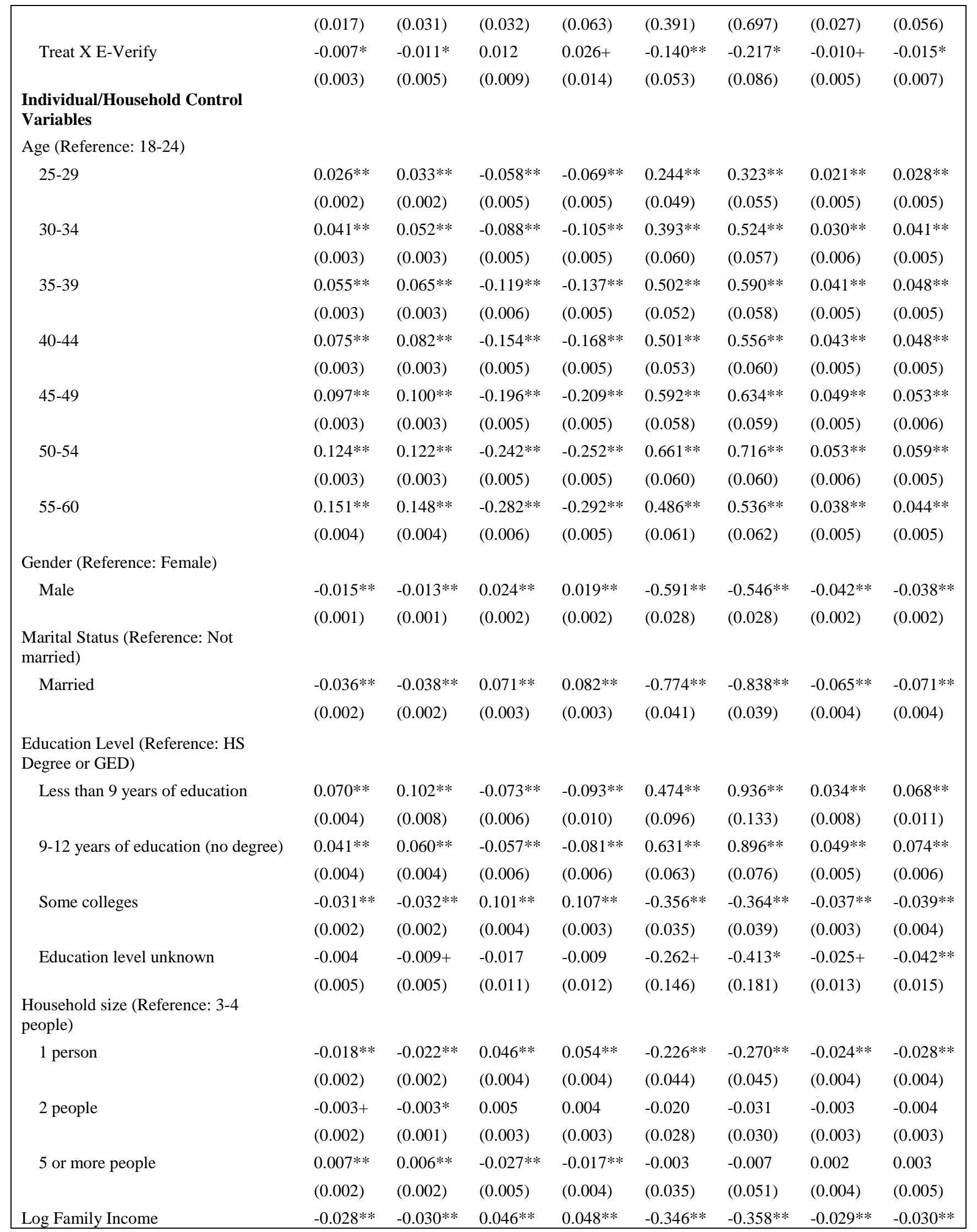




\begin{tabular}{|c|c|c|c|c|c|c|c|c|}
\hline & $(0.001)$ & $(0.001)$ & $(0.002)$ & $(0.002)$ & $(0.021)$ & $(0.024)$ & $(0.002)$ & $(0.002)$ \\
\hline $\begin{array}{l}\text { Interview Language - Not English } \\
\text { Years Since Arrival (Reference: US- } \\
\text { born) }\end{array}$ & $\begin{array}{l}0.019 * * \\
(0.004)\end{array}$ & $\begin{array}{l}0.018^{* *} \\
(0.006)\end{array}$ & $\begin{array}{l}-0.061 * * \\
(0.009)\end{array}$ & $\begin{array}{l}-0.063 * * \\
(0.013)\end{array}$ & $\begin{array}{l}0.142+ \\
(0.074)\end{array}$ & $\begin{array}{l}0.227^{*} \\
(0.106)\end{array}$ & $\begin{array}{l}0.011+ \\
(0.007)\end{array}$ & $\begin{array}{l}0.017+ \\
(0.010)\end{array}$ \\
\hline $0-5$ Years & $\begin{array}{l}0.021+ \\
(0.010)\end{array}$ & $\begin{array}{l}-0.030 \\
(0.021)\end{array}$ & $\begin{array}{l}-0.034 \\
(0.024)\end{array}$ & $\begin{array}{l}0.072 * \\
(0.035)\end{array}$ & $\begin{array}{l}-0.204 \\
(0.195)\end{array}$ & $\begin{array}{l}-0.663^{*} \\
(0.285)\end{array}$ & $\begin{array}{l}-0.011 \\
(0.018)\end{array}$ & $\begin{array}{l}-0.026 \\
(0.025)\end{array}$ \\
\hline 6-10 Years & $\begin{array}{l}0.022 * \\
(0.009)\end{array}$ & $\begin{array}{l}-0.024 \\
(0.019)\end{array}$ & $\begin{array}{l}-0.054 * * \\
(0.021)\end{array}$ & $\begin{array}{l}0.043 \\
(0.033)\end{array}$ & $\begin{array}{l}-0.106 \\
(0.178)\end{array}$ & $\begin{array}{l}-0.493+ \\
(0.290)\end{array}$ & $\begin{array}{l}-0.002 \\
(0.016)\end{array}$ & $\begin{array}{l}-0.011 \\
(0.025)\end{array}$ \\
\hline 11-15 Years & $\begin{array}{l}0.017^{*} \\
(0.008)\end{array}$ & $\begin{array}{l}-0.023 \\
(0.018)\end{array}$ & $\begin{array}{l}-0.052 * \\
(0.020)\end{array}$ & $\begin{array}{l}0.041 \\
(0.031)\end{array}$ & $\begin{array}{l}-0.254 \\
(0.178)\end{array}$ & $\begin{array}{l}-0.749 * \\
(0.294)\end{array}$ & $\begin{array}{l}-0.015 \\
(0.015)\end{array}$ & $\begin{array}{l}-0.027 \\
(0.026)\end{array}$ \\
\hline $15+$ Years & $\begin{array}{l}0.032 * * \\
(0.008)\end{array}$ & $\begin{array}{l}0.006 \\
(0.015)\end{array}$ & $\begin{array}{l}-0.065^{* *} \\
(0.019)\end{array}$ & $\begin{array}{l}0.027 \\
(0.026)\end{array}$ & $\begin{array}{l}-0.192 \\
(0.155)\end{array}$ & $\begin{array}{l}-0.975^{* *} \\
(0.261)\end{array}$ & $\begin{array}{l}-0.011 \\
(0.014)\end{array}$ & $\begin{array}{l}-0.044+ \\
(0.024)\end{array}$ \\
\hline YSI Unknown & $\begin{array}{l}0.010 \\
(0.009)\end{array}$ & $\begin{array}{l}-0.026 \\
(0.023)\end{array}$ & $\begin{array}{l}-0.067^{* *} \\
(0.024)\end{array}$ & $\begin{array}{l}0.015 \\
(0.042)\end{array}$ & $\begin{array}{l}-0.313 \\
(0.244)\end{array}$ & $\begin{array}{l}-0.982 * \\
(0.425)\end{array}$ & $\begin{array}{l}-0.020 \\
(0.022)\end{array}$ & $\begin{array}{l}-0.035 \\
(0.037)\end{array}$ \\
\hline \multicolumn{9}{|l|}{$\begin{array}{l}\text { Cohort of Arrival (Reference: Before } \\
\text { 1987) }\end{array}$} \\
\hline $1987-1991$ & $\begin{array}{l}-0.033^{* *} \\
(0.004)\end{array}$ & $\begin{array}{l}-0.022+ \\
(0.013)\end{array}$ & $\begin{array}{l}0.020^{* *} \\
(0.007)\end{array}$ & $\begin{array}{l}-0.027 \\
(0.017)\end{array}$ & $\begin{array}{l}-0.225^{* *} \\
(0.073)\end{array}$ & $\begin{array}{l}-0.301 \\
(0.198)\end{array}$ & $\begin{array}{l}-0.027^{* *} \\
(0.008)\end{array}$ & $\begin{array}{l}-0.048^{*} \\
(0.018)\end{array}$ \\
\hline 1992-1996 & $\begin{array}{l}-0.033^{* *} \\
(0.006)\end{array}$ & $\begin{array}{l}-0.014 \\
(0.016)\end{array}$ & $\begin{array}{l}0.021^{*} \\
(0.010)\end{array}$ & $\begin{array}{l}-0.019 \\
(0.022)\end{array}$ & $\begin{array}{l}-0.331^{* *} \\
(0.100)\end{array}$ & $\begin{array}{l}-0.336 \\
(0.212)\end{array}$ & $\begin{array}{l}-0.033^{* *} \\
(0.009)\end{array}$ & $\begin{array}{l}-0.045^{*} \\
(0.020)\end{array}$ \\
\hline $1997-2001$ & $\begin{array}{l}-0.043^{* *} \\
(0.008)\end{array}$ & $\begin{array}{l}-0.024 \\
(0.018)\end{array}$ & $\begin{array}{l}0.030^{*} \\
(0.012)\end{array}$ & $\begin{array}{l}-0.002 \\
(0.027)\end{array}$ & $\begin{array}{l}-0.551^{* *} \\
(0.124)\end{array}$ & $\begin{array}{l}-0.632^{* *} \\
(0.217)\end{array}$ & $\begin{array}{l}-0.053^{* *} \\
(0.012)\end{array}$ & $\begin{array}{l}-0.061^{* *} \\
(0.020)\end{array}$ \\
\hline $2002-2013$ & $\begin{array}{l}-0.056^{* *} \\
(0.010)\end{array}$ & $\begin{array}{l}-0.034+ \\
(0.019)\end{array}$ & $\begin{array}{l}0.029+ \\
(0.017)\end{array}$ & $\begin{array}{l}-0.020 \\
(0.031)\end{array}$ & $\begin{array}{l}-0.659 * * \\
(0.144)\end{array}$ & $\begin{array}{l}-0.803^{* *} \\
(0.275)\end{array}$ & $\begin{array}{l}-0.067 * * \\
(0.015)\end{array}$ & $\begin{array}{l}-0.085^{* *} \\
(0.024)\end{array}$ \\
\hline Cohort unknown & $\begin{array}{l}-0.030 * * \\
(0.007)\end{array}$ & $\begin{array}{l}-0.039 * \\
(0.019)\end{array}$ & $\begin{array}{l}0.009 \\
(0.013)\end{array}$ & $\begin{array}{l}-0.010 \\
(0.029)\end{array}$ & $\begin{array}{l}-0.581^{* *} \\
(0.134)\end{array}$ & $\begin{array}{l}-0.688^{*} \\
(0.337)\end{array}$ & $\begin{array}{l}-0.045^{* *} \\
(0.011)\end{array}$ & $\begin{array}{l}-0.065^{*} \\
(0.027)\end{array}$ \\
\hline \multicolumn{9}{|l|}{ Citizenship (Reference: NonCitizen) } \\
\hline Citizen & $\begin{array}{l}0.016^{* *} \\
(0.004)\end{array}$ & & $\begin{array}{l}-0.025^{* *} \\
(0.006)\end{array}$ & & $\begin{array}{l}0.302 * * \\
(0.075)\end{array}$ & & $\begin{array}{l}0.015^{*} \\
(0.007)\end{array}$ & \\
\hline \multicolumn{9}{|l|}{$\begin{array}{l}\text { Sending regions (Reference: Non- } \\
\text { Mexican Central American) }\end{array}$} \\
\hline South American & $\begin{array}{l}-0.014^{* *} \\
(0.005)\end{array}$ & $\begin{array}{l}-0.015+ \\
(0.008)\end{array}$ & $\begin{array}{l}0.016 \\
(0.015)\end{array}$ & $\begin{array}{l}0.035 \\
(0.024)\end{array}$ & $\begin{array}{l}0.268 * \\
(0.134)\end{array}$ & $\begin{array}{l}0.178 \\
(0.240)\end{array}$ & $\begin{array}{l}0.026^{*} \\
(0.012)\end{array}$ & $\begin{array}{l}0.017 \\
(0.019)\end{array}$ \\
\hline Mexican & $\begin{array}{l}-0.027 * * \\
(0.005)\end{array}$ & $\begin{array}{l}-0.035^{* *} \\
(0.006)\end{array}$ & $\begin{array}{l}0.014 \\
(0.013)\end{array}$ & $\begin{array}{l}0.022 \\
(0.017)\end{array}$ & $\begin{array}{l}-0.429 * * \\
(0.108)\end{array}$ & $\begin{array}{l}-0.685^{* *} \\
(0.167)\end{array}$ & $\begin{array}{l}-0.032 * * \\
(0.008)\end{array}$ & $\begin{array}{l}-0.049 * * \\
(0.012)\end{array}$ \\
\hline Constant & $\begin{array}{l}0.301^{* *} \\
(0.014)\end{array}$ & $\begin{array}{l}0.335 * * \\
(0.015)\end{array}$ & $\begin{array}{l}0.315^{* *} \\
(0.026)\end{array}$ & $\begin{array}{l}0.259 * * \\
(0.029)\end{array}$ & $\begin{array}{l}5.979 * * \\
(0.299)\end{array}$ & $\begin{array}{l}6.418^{* *} \\
(0.310)\end{array}$ & $\begin{array}{l}0.463 * * \\
(0.025)\end{array}$ & $\begin{array}{l}0.489 * * \\
(0.026)\end{array}$ \\
\hline $\mathrm{N}$ & 243426 & 191133 & 243426 & 191133 & 99300 & 82770 & 99300 & 82770 \\
\hline
\end{tabular}

Note: $+0.1>p \geq 0.05, * 0.05>p \geq 0.01, * * p<0.01$. Each column for each outcome is based on a separate regression. The analysis is restricted to counties with at least 20 Latino non-citizen observations across survey years. The samples of analyses are adults aged 18-60 years. Treat 1 is foreign-born Hispanic with at least 1 non-citizen household member, treat 2 is foreign-born Hispanic with only non-citizen household members, and the comparison group is U.S. born Non-Hispanic white adults. In addition to the coefficients reported above, all models control for county and year fixed effects. Standard errors clustered on county of residence are in parenthesis. Shaded areas are results presented in Table 2. 